\title{
12. SEDIMENTOLOGY OF MARINE CRETACEOUS SEQUENCES IN THE CENTRAL EXMOUTH PLATEAU (NORTHWEST AUSTRALIA) ${ }^{1}$
}

\author{
N. F. Exon, ${ }^{2}$ P. E. Borella, ${ }^{3}$ and M. Ito ${ }^{4}$
}

\begin{abstract}
Sites 762 and 763 were both drilled on the central Exmouth Plateau in water depths of about $1380 \mathrm{~m}$. At Site 763 , $1036 \mathrm{~m}$ were drilled about $100 \mathrm{~km}$ northeast of the Cuvier Abyssal Plain, and at Site $762,940 \mathrm{~m}$ were drilled about $80 \mathrm{~km}$ to the north of Site 763 . At both sites we recovered continuous core from fairly complete Cenozoic and Cretaceous sequences; the Cretaceous sequence is $790 \mathrm{~m}$ thick in Site 763 and $385 \mathrm{~m}$ thick in Site 762 . Site 763 has an expanded Early Cretaceous sequence, and Site 762 has an expanded Late Cretaceous sequence.

The Cretaceous sequence rests either on a very condensed Jurassic shelf sequence or on Triassic sediments. It commences with Berriasian deltaic mudstone and sandstone (Barrow Group) which built rapidly northward. After late Valanginian breakup of Gondwanaland, there was a hiatus before Hauterivian to early Aptian marine mudstone (Muderong Shale) was deposited following a marine transgression. A late Aptian hiatus was followed by deposition of Albian mudstone and marl (Gearle Siltstone) and late Albian to Coniacian marl (Haycock Marl).

Pure pelagic carbonate sedimentation started in the Santonian (Toolonga Calcilutite), and the remainder of the Cretaceous consists of chalks.

Sedimentation rates in the Berriasian were about $150 \mathrm{~m} / \mathrm{m} . y$. near Site 763 and less to the north. In the remainder of the Cretaceous they seldom exceeded $20 \mathrm{~m} / \mathrm{m}$.y. Both tectonic events and eustatic sea-level changes are reflected in the sediments. Color cycles in the marls and chalks can be related to the Milankovitch orbital precession (21 k.y.) and obliquity (41 k.y.) cycles.
\end{abstract}

\section{INTRODUCTION}

The aim of this paper is to describe the sedimentology of the Cretaceous sequences at Ocean Drilling Program (ODP) Sites 762 and 763 on the central Exmouth Plateau (Fig. 1), and to use the results, in conjunction with other data from the sites and elsewhere, to outline the Cretaceous sedimentary history of the region. The Exmouth Plateau is a northwesterly projection of the Australian continent, surrounded on three sides by abyssal plains, and has a sedimentary section about $10 \mathrm{~km}$ thick, including a Cretaceous-Cenozoic section of highly variable thickness of up to $2000 \mathrm{~m}$ (Exon and Willcox, 1980). Sites 762 and 763 are in an area where $3000 \mathrm{~m}$ of faulted Triassic fluviodeltaic sediments are overlain by a very condensed Jurassic shelf sequence, a Berriasian deltaic sequence up to $1500 \mathrm{~m}$ thick that had built northward, and a late Neocomian and younger sequence $(500-800 \mathrm{~m}$ thick) that documents the Cretaceous sinking of the plateau to bathyal depths. The Cretaceous sequence is $790 \mathrm{~m}$ thick in Site 763, and $385 \mathrm{~m}$ thick in Site 762 .

A composite stratigraphic diagram (Fig. 2) shows the general results from the two sites and Vinck No. 1 well; the most expanded sequences drilled in the holes have been selected. It shows marine Berriasian prodelta mudstones 700 $\mathrm{m}$ thick, overlain by $100 \mathrm{~m}$ of transgressive HauterivianAlbian shelf mudstone, $350 \mathrm{~m}$ of Albian-Maastrichtian chalk and marl, and $550 \mathrm{~m}$ of Cenozoic chalk and ooze. Seismic profile ODP 122-6 connects Sites 762 and 763, and illustrates how the various seismic sequences (1-8 after Haq, von Rad, O'Connell, et al., 1990) thicken and thin in a north-south

\footnotetext{
1 von Rad, U., Haq, B. U., et al., 1992. Proc. ODP, Sci. Results, 122: College Station, TX (Ocean Drilling Program).

2 Bureau of Mineral Resources, P.O. Box 378, Canberra 2601, Australia.

3 Geology Department, Saddleback College, Mission Viejo, CA 92692 , U.S.A.

${ }^{4}$ Geological Institute, Chiba University, Chiba 260, Japan.
}

direction (Fig. 3). The most spectacular change is in the northerly-thinning wedge of Valanginian-Berriasian sediments, which is dominated by the prodelta sediments of the Barrow delta derived from the south (Exon and Buffler, this volume).

\section{TECHNIQUES}

Nearly 100 samples of $10-\mathrm{cm}^{3}$ from cores from Sites 762 and 763 were processed in the Bureau of Mineral Resources (BMR) marine sedimentology laboratory in Canberra (Tables 1 and 2). Smear slides were made of those which could be disaggregated, and they were then wet sieved into three fractions ( $>2 \mathrm{~mm}, 2 \mathrm{~mm}-63 \mu \mathrm{m},<63 \mu \mathrm{m}$ ). After ultrasonic disaggregation, the fine fraction was run through a Micromeritics SediGraph 5100 to measure the grain size in the fine fraction. The SediGraph uses X-radiation to detect relative particle concentrations, using the principle that larger particles fall faster in a column of water than do small ones. The fine fraction was later used for carbonate analysis in a carbonate bomb.

The coarse fraction ( $>63 \mu \mathrm{m}$ ) of each sample was examined semiquantitatively under a binocular microscope and the various components recorded. Additional information came from thin sections of harder material, smear slides, shipboard descriptions, $\mathrm{CaCO}_{3}$ and organic carbon analyses, and core photographs, and post-cruise semi-quantitative X-ray studies (Wilkens et al., this volume). In addition we dated and correlated our results by reference to shipboard (Haq, von Rad, O'Connell, 1990) and post-cruise paleontological, seismic stratigraphic, and well-log studies. The coarse fraction of the lower part of Hole $763 \mathrm{C}$ was petrologically examined by Ito by point-counting under a binocular microscope, and the results are summarized in Table 3.

\section{REGIONAL CRETACEOUS GEOLOGY}

The north Carnarvon Basin is an offshore basin which includes the Exmouth Plateau (Cockbain, 1989). The basin is 


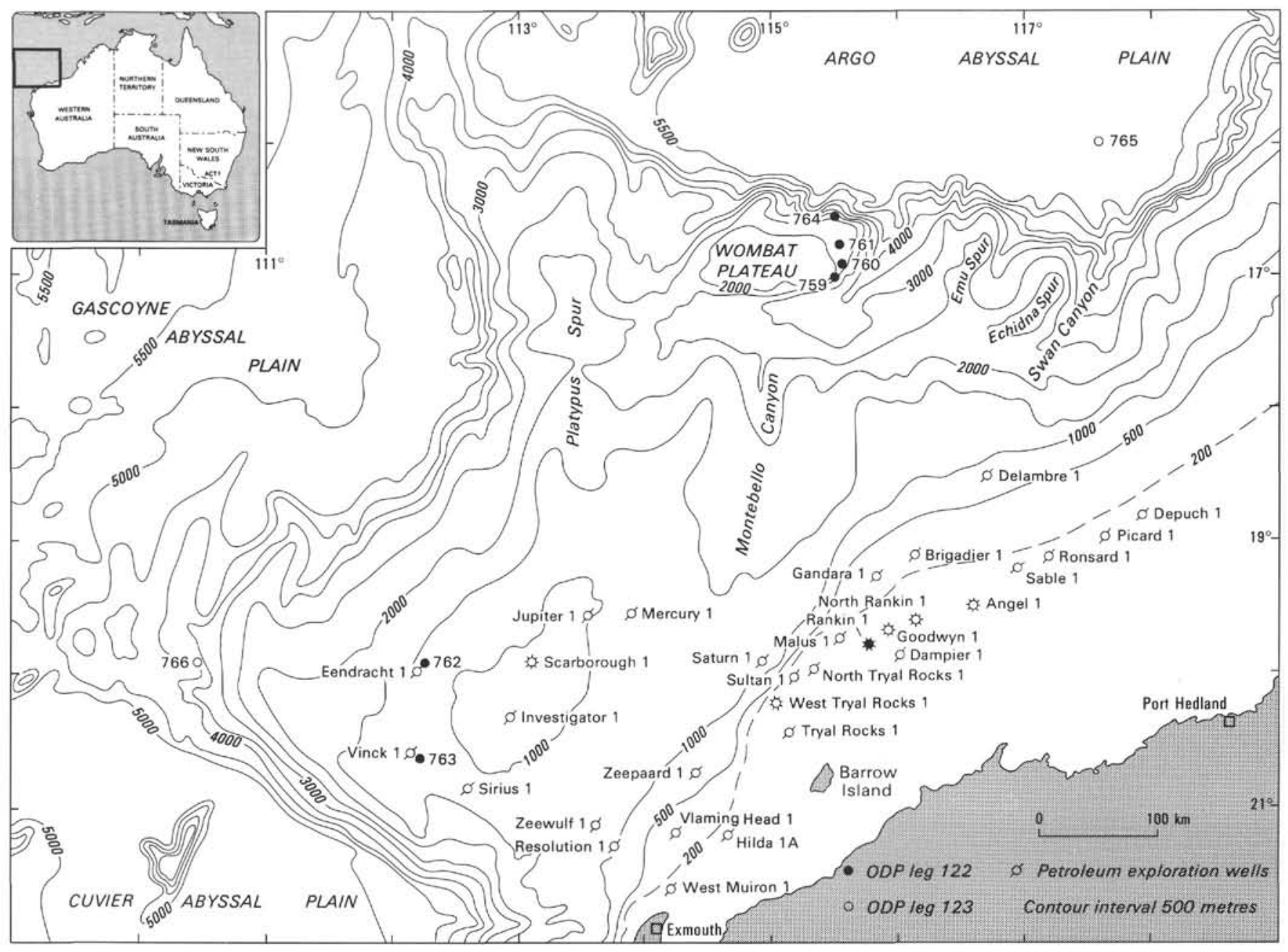

Figure 1. Exmouth Plateau bathymetric map showing locations of ODP sites (open and solid circles) and commercial petroleum exploration wells (standard industry symbols).

best known on land and beneath the Northwest Shelf, where it extends from southwest of Exmouth to north of Port Hedland (Fig. 1), and where a large number of petroleum exploration wells have been drilled. It contains three subbasins on the Northwest Shelf: from northeast to southwest they are the Dampier, Barrow, and Exmouth sub-basins. The basin is limited to the east by a number of down-to-the-basin faults $50-100 \mathrm{~km}$ offshore, beyond which are older rocks of the Peedamullah Shelf. On this shelf a veneer of Cretaceous rocks sits on Paleozoic sediments. The basin is part of the Westralian Superbasin (Yeates et al., 1987; Bradshaw et al., 1988), a Permian and Mesozoic depocenter containing about $10 \mathrm{~km}$ of sedimentary rocks and extending along the western margin of Australia, from the Bonaparte Basin in the north to the southernmost part of the Carnarvon Basin in the south. The superbasin formed part of the northern margin of Gondwanaland and southern margin of Tethys until Gondwanaland broke up in latest Jurassic and earliest Cretaceous times.

Bradshaw et al. (1988) summarize the regional stratigraphy as follows. Triassic sequences characterize the Westralian Superbasin. They are largely clastic, with fine-grained marine shales near the base, and fluviodeltaic sequences toward the top. In the Jurassic the superbasin was divided into platforms and troughs, with thick marine shales filling northeasterlytrending depocenters, but very little or no sedimentation on high areas like the central and western Exmouth Plateau. Cretaceous sediments blanket the entire region, covering the infilled Jurassic surface with deltaic sands and marine shales overlain by Late Cretaceous and Cenozoic carbonates.

The Cretaceous sequences of the Exmouth Plateau are much the same as those elsewhere in the north Carnarvon Basin, which have been studied extensively as the result of petroleum exploration. Most major Cretaceous oil discoveries have been in the Neocomian sequences of the Barrow Subbasin near Barrow Island (McClure et al., 1988).

Excellent summaries of various aspects of the Cretaceous stratigraphy of the Carnarvon Basin have been provided, among others, by Powell (1976), Hocking et al. (1987, whole basin), Apthorpe (1979, Northwest Shelf Upper Cretaceous), Eriyagama et al. (1988, Lower Cretaceous in Barrow Subbasin), Woodside Offshore Petroleum (1988, Barrow and Dampier sub-basins), Parry and Smith (1988, Barrow and Exmouth sub-basins), and Boote and Kirk (1989, Mesozoic wedge cycles in whole basin). Reviews of Cretaceous sequences on the Exmouth Plateau include those of Wright and Wheatley (1979), Exon and Willcox (1980), Barber (1982, 1988), Erskine and Vail (1988), and Haq, von Rad, O'Connell, et al. (1990). The history of the adjacent abyssal plains is outlined by Veevers, Heirtzler, et al. (1974), Fullerton et al. (1989), and Ludden, Gradstein, et al. (1990). The stratigraphic 


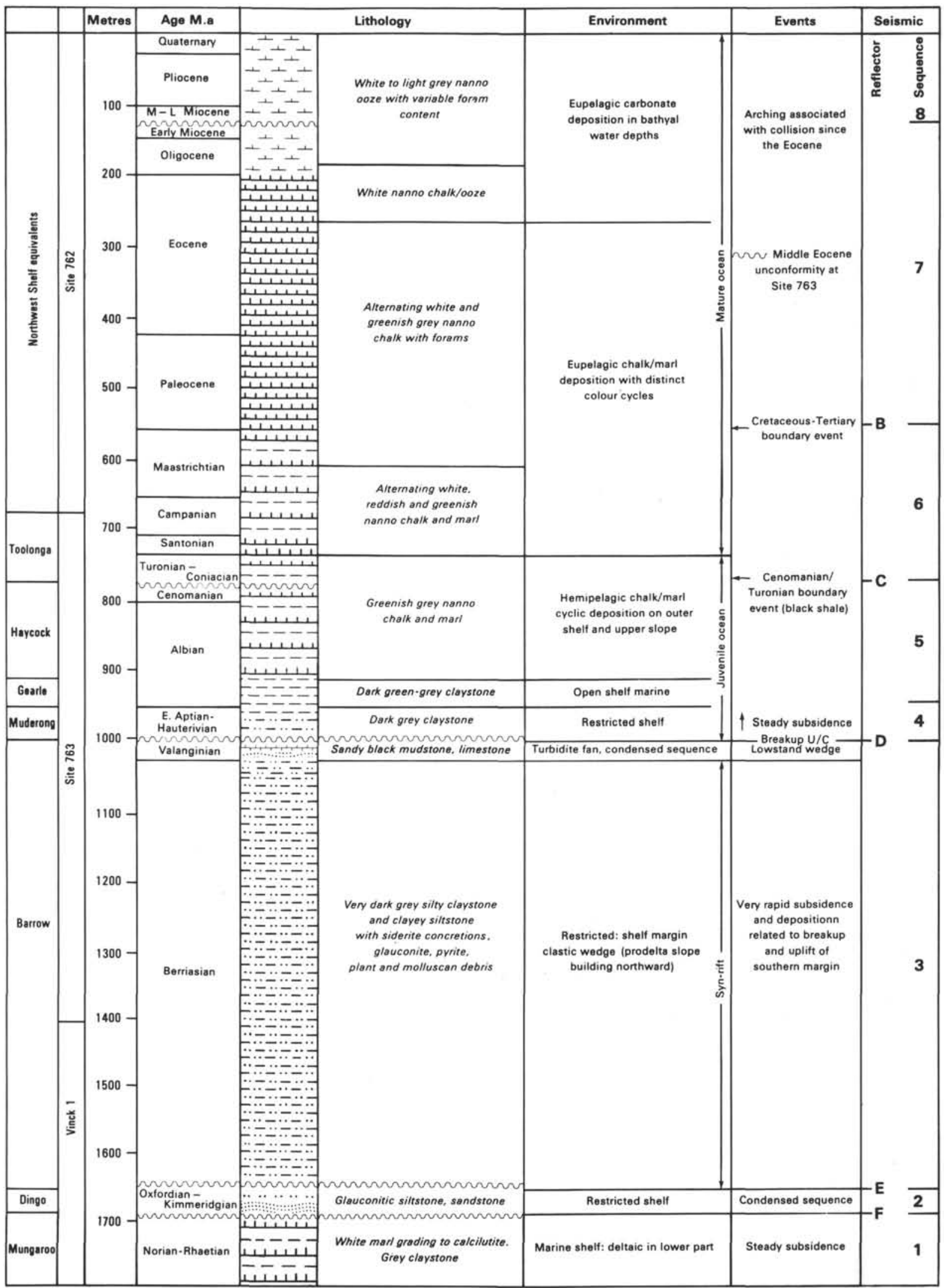

Figure 2. Composite lithological log for Sites 762 and 763, and Esso Vinck No. 1 well (near Site 763), showing major geological events and correlation to seismic reflectors and sequences. 


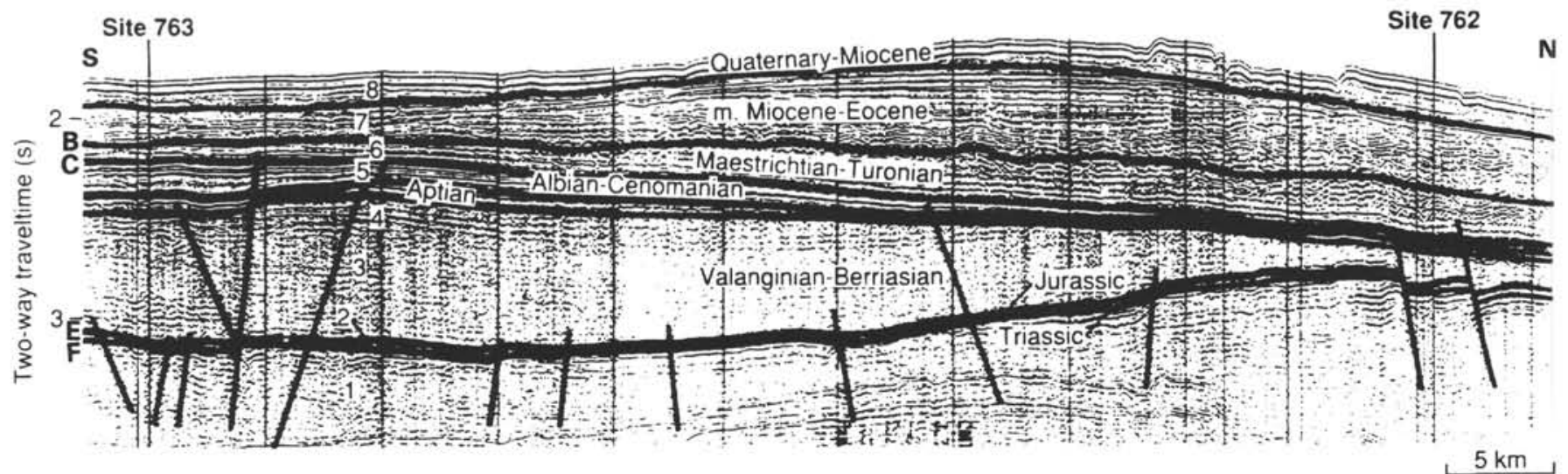

Figure 3. Seismic profile ODP 122-6, between Sites 762 and 763, showing alphabetical reflector nomenclature of Willcox and Exon (1976), numerical ODP seismic sequence nomenclature, and approximate ages of seismic sequences. From Haq, von Rad, O'Connell, et al. (1990). Site locations are shown in Figure 1.

nomenclature we use in this paper and the brief descriptions below are drawn from Hocking et al. (1987).

\section{Barrow Group}

The Barrow Group is a deltaic complex which prograded northward in the Barrow Sub-basin and across the southern Exmouth Plateau. In the Barrow Sub-basin, it contains two formations-the lower, the Malouet Formation, consists of basinal sandstone facies or bottom sets. The upper, the Flacourt Formation, consists of a prodelta claystone facies overlain by a delta front and delta plain quartz sandstone facies. The type section of the Barrow Group is in Barrow No. 1 well on Barrow Island, between $909 \mathrm{~m}$ and $2181 \mathrm{~m}$. Where it is well developed it is commonly $500-1500 \mathrm{~m}$ thick. Pyrite and glauconite are common in the Malouet Formation, and pyrite in the Flacourt Formation. Spores, pollen, and microplankton indicate that the age of the group ranges from latest Jurassic to Valanginian (Wiseman, 1979).

\section{Muderong Shale}

The Muderong Shale is the lowest formation in the Winning Group, which also includes the Windalia Radiolarite, Gearle Siltstone, and Haycock Marl at Sites 762 and 763. In the Barrow Sub-basin, and on the Exmouth Plateau, the Muderong Shale sits directly but unconformably on the Barrow Group. Its type section $\left(24^{\circ} 8^{\prime} 3^{\prime \prime} \mathrm{S}, 114^{\circ} 45^{\prime} 49^{\prime \prime} \mathrm{E}\right)$ is $2 \mathrm{~km}$ southwest of Twins Bore on Middalya Station. In the Carnarvon Basin as a whole it consists dominantly of argillaceous siltstone with lenses of quartzose sandstone. It reaches a thickness of $300 \mathrm{~m}$ or more in offshore basinal depocenters, but is much thinner onshore. Glauconite and pyrite are common accessory minerals. The formation was deposited in lowenergy, offshore marine conditions, as the result of the Neocomian transgression, and its base is diachronous. Spores, pollen, and microplankton date its maximum range as Valanginian to late Aptian (Wiseman, 1979).

\section{Windalia Radiolarite}

The Windalia Radiolarite cannot be distinguished from the Gearle Siltstone in Sites 762 and 763, where a combined unit unconformably overlies the Muderong Shale. In the Carnarvon Basin as a whole the formation is distinctive in outcrop, but only recognizable in the subsurface in wireline logs where, compared with the underlying Muderong Shale, it has reduced gamma-ray and sonic log signatures. Its type section at Windalia Hill $\left(23^{\circ} 16^{\prime} \mathrm{S}, 114^{\circ} 48^{\prime} \mathrm{E}\right)$ is $36 \mathrm{~m}$ thick. In the subsurface it is up to $30 \mathrm{~m}$ thick and consists of lithologies ranging from siltstone to calcilutite, with a radiolarian content of $5 \%-70 \%$. Quartz sand grains, glauconite, and pyrite are common constituents, and bentonite is a minor one. The nearshore siltstone facies is shallow marine, but the offshore calcilutite facies was deposited in outer shelf depths and grades into the Haycock Marl. The fauna includes poorly preserved radiolarians and foraminifers, as well as ammonites, belemnites, and bivalves. Spores, pollen, microplankton, and ostracodes have been used to date it as latest Aptian to earliest Albian in age (e.g., Helby et al., 1987).

\section{Gearle Siltstone}

The Gearle Siltstone is indistinguishable from the Windalia Radiolarite at Sites 762 and 763. The combined unit unconformably overlies the Muderong Shale on the central Exmouth Plateau. The type section of the Gearle Siltstone is in C-Y Creek $\left(22^{\circ} 54^{\prime} \mathrm{S}, 114^{\circ} 9^{\prime} \mathrm{E}\right)$ in the Giralia Anticline south of Exmouth (see Fig. 1). In the Carnarvon Basin generally the Gearle Siltstone is a mudstone sequence containing appreciable radiolarian siltstone, which conformably overlies the Windalia Radiolarite. It is generally somewhat calcareous, with concretions and thin lenses of limestone, and it contains glauconite in an upper member. Its maximum thickness is 700 $m$ in the area around Tryal Rocks No. 1 well north of Barrow Island (Fig. 1). The formation was deposited in low-energy, offshore marine conditions with limited terrigenous input. It contains a variety of foraminifers, belemnites, and bivalves, and is Albian to Turonian in age (Belford and Scheibnerova, 1972).

\section{Haycock Marl}

The Haycock Marl (Heath and Apthorpe, 1984) conformably overlies the Gearle Siltstone at Sites 762 and 763. It is a lateral, more calcareous facies equivalent to all or part of the Gearle Siltstone. Well offshore in the northern and western Carnarvon Basin, it lies between the Windalia Radiolarite and the Toolonga Calcilutite. Its type section is in Goodwyn No. 6 on the Rankin Platform (near Goodwyn No. 1 well on Fig. 1), between $2687.5 \mathrm{~m}$ and $2738 \mathrm{~m}$, and it is up to $250 \mathrm{~m}$ thick. It consists of two units of clayey calcilutite and marl, separated by a thin persistent shale unit. 
Table 1. Sedimentological results, Hole $762 \mathrm{C}$.

\begin{tabular}{|c|c|c|c|c|c|c|}
\hline $\begin{array}{l}\text { Depth } \\
\text { (mbsf) }\end{array}$ & $\begin{array}{l}\text { Core, section, } \\
\text { interval }(\mathrm{cm})\end{array}$ & $\begin{array}{l}\text { Sand } \\
(\%)\end{array}$ & $\begin{array}{l}\text { Mud } \\
(\%)\end{array}$ & $\begin{array}{c}\text { Carbonate } \\
(\%)\end{array}$ & $\underset{(\mu \mathrm{m})}{\text { Median }}$ & $\begin{array}{l}\text { Mode } \\
(\mu \mathrm{m})\end{array}$ \\
\hline \multicolumn{7}{|c|}{$122-762 C$ - } \\
\hline 351.33 & $21 X-1,83-85$ & 1.7 & 98.3 & 80.0 & & \\
\hline 368.46 & $22 X-6,95-97$ & 2.4 & 97.6 & 76.0 & 2.73 & 3.37 \\
\hline 371.80 & $23 X-2,79-81$ & 1.7 & 98.3 & 26.0 & & \\
\hline 392.73 & $25 \mathrm{X}-3,122-124$ & 2.7 & 97.3 & 76.0 & & \\
\hline 400.41 & $26 \times-2,90-92$ & 2.6 & 97.4 & 67.0 & 4.05 & 3.79 \\
\hline 404.23 & $27 X-3,22-24$ & 3.4 & 96.6 & 70.0 & & \\
\hline 408.21 & $27 X-4,120-122$ & 1.9 & 98.1 & 54.0 & 1.79 & 2.89 \\
\hline 412.85 & $28 X-1,84-86$ & 2.4 & 97.6 & 90.0 & 2.92 & 3.12 \\
\hline 423.15 & $29 X-2,14-16$ & 5.8 & 94.2 & 84.0 & 3.53 & 3.98 \\
\hline 435.65 & $30 \times-4,65-67$ & 9.2 & 90.8 & 87.0 & 2.60 & 3.20 \\
\hline 444.24 & $31 X-3,73-76$ & 5.8 & 94.2 & 93.0 & 2.63 & 2.59 \\
\hline 451.98 & $32 \times-2,47-49$ & 6.0 & 94.0 & 93.0 & 2.93 & 3.03 \\
\hline 463.22 & $33 X-3,71-73$ & 5.0 & 95.0 & 90.0 & 2.71 & 2.97 \\
\hline 472.72 & $34 X-3,71-74$ & 5.1 & 94.9 & 80.0 & 3.04 & 3.22 \\
\hline 480.98 & $35 X-2,97-100$ & 3.7 & 96.3 & 87.0 & 2.82 & 3.53 \\
\hline 488.43 & $36 \mathrm{X}-\mathrm{CC}, 17-19$ & 3.5 & 96.5 & 84.0 & 1.92 & 2.24 \\
\hline 499.60 & $37 X-2,60-61$ & 2.0 & 98.0 & 87.0 & 2.48 & 2.92 \\
\hline 512.56 & $38 X-4,105-107$ & 4.3 & 95.7 & 70.0 & 2.40 & 2.82 \\
\hline 517.11 & $39 X-1,60-62$ & 2.7 & 97.3 & 28.0 & 1.46 & 2.46 \\
\hline 529.67 & $40 X-3,66-68$ & 4.9 & 95.1 & 54.0 & 2.50 & 3.07 \\
\hline 539.07 & $41 X-3,56-58$ & 0.7 & 99.3 & 54.0 & 2.83 & 3.56 \\
\hline 550.03 & $42 X-4,102-104$ & 2.3 & 97.7 & 13.0 & 1.41 & 2.41 \\
\hline 561.20 & $43 X-5,69-71$ & 4.7 & 95.3 & 88.0 & 2.48 & 3.40 \\
\hline 567.56 & $44 X-3,55-57$ & 9.7 & 90.3 & 88.0 & 2.16 & 2.59 \\
\hline 578.07 & $45 X-4,6-8$ & 4.5 & 95.5 & 90.0 & 2.20 & 2.94 \\
\hline 584.15 & $46 X-2,64-66$ & 9.7 & 90.3 & 93.0 & 2.75 & 3.20 \\
\hline 612.69 & $49 X-1,134-136$ & 9.8 & 90.2 & 75.0 & 2.29 & 2.04 \\
\hline 622.69 & $50 X-2,18-20$ & 11.4 & 88.6 & 84.0 & 2.83 & 3.38 \\
\hline 646.53 & $52 X-5,52-54$ & 4.5 & 95.5 & 89.0 & 2.43 & 3.55 \\
\hline 651.94 & $53 \mathrm{X}-2,93-95$ & 7.5 & 92.5 & 87.0 & 2.47 & 2.55 \\
\hline 665.09 & $54 X-5,8-10$ & 7.7 & 92.3 & 64.0 & 1.93 & 1.21 \\
\hline 672.04 & $55 X-3,53-55$ & 1.8 & 98.2 & 82.0 & 2.27 & 2.53 \\
\hline 681.55 & $56 \times-3,54-56$ & 4.4 & 95.6 & 82.0 & 2.22 & 1.45 \\
\hline 689.34 & $57 X-2,33-35$ & 5.3 & 94.7 & 76.0 & 2.88 & 3.94 \\
\hline 698.84 & $59 X-3,86-88$ & 8.4 & 91.6 & 87.0 & 2.68 & 2.94 \\
\hline 746.52 & $63 X-2,52-53$ & 10.7 & 89.3 & 90.0 & 2.79 & 1.87 \\
\hline 769.98 & $66 \times-4,47-49$ & 8.7 & 91.3 & 90.0 & 3.41 & 4.15 \\
\hline 785.27 & $70 \times-1,26-28$ & 7.7 & 92.3 & 92.0 & 1.72 & 2.28 \\
\hline 790.06 & $71 X-1,6-8$ & 18.7 & 81.3 & 70.0 & 3.35 & 3.90 \\
\hline 796.98 & $72 \times-2,47-49$ & 2.8 & 97.2 & 51.0 & 2.83 & 2.84 \\
\hline 802.11 & $73 X-2,110-112$ & 8.8 & 91.2 & 65.0 & 3.38 & 3.70 \\
\hline 806.77 & $74 X-2,76-79$ & 9.0 & 91.0 & 87.0 & 3.63 & 4.15 \\
\hline 809.91 & $75 X-1,40-42$ & 22.7 & 35.1 & 70.0 & 3.23 & 2.81 \\
\hline 810.30 & $75 X-1,79-81$ & 41.2 & 58.6 & 55.0 & 1.66 & 1.39 \\
\hline 810.50 & $75 X-1,99-101$ & 15.5 & 84.5 & 50.0 & 2.50 & 2.19 \\
\hline 810.82 & $75 X-1,131-133$ & 32.1 & 67.9 & 7.0 & 2.07 & 1.74 \\
\hline 810.88 & $75 \mathrm{X}-1,137-139$ & 8.0 & 92.0 & 50.0 & 3.14 & 2.47 \\
\hline 818.06 & $76 \times-3,55-57$ & 8.6 & 91.4 & 74.0 & 3.24 & 4.08 \\
\hline 826.68 & $77 X-5,117-119$ & 12.5 & 87.5 & 75.0 & 3.16 & 3.53 \\
\hline 829.51 & $78 \times-1,50-52$ & 2.3 & 97.7 & 81.5 & 2.11 & 2.12 \\
\hline 839.02 & $79 \times-1,50-52$ & 14.6 & 85.4 & 4.0 & 3.94 & 4.59 \\
\hline 856.17 & $82 X-2,117-118$ & 0.9 & 99.1 & 3.0 & 3.39 & 7.73 \\
\hline 874.29 & $85 X-1,128-130$ & 1.9 & 98.1 & 3.0 & 3.18 & 4.71 \\
\hline 884.91 & $86 X-2,90-92$ & 0.9 & 99.1 & 3.0 & 2.33 & 4.02 \\
\hline 893.08 & $87 X-1,127-129$ & 1.8 & 98.2 & 3.0 & 2.76 & 11.39 \\
\hline 902.65 & $88 X-1,114-116$ & 17.0 & 83.0 & 2.0 & 4.92 & 9.42 \\
\hline 914.64 & $89 X-3,63-65$ & 3.3 & 96.1 & 4.0 & 5.91 & 21.30 \\
\hline 925.46 & $90 \times-4,45-47$ & 9.3 & 90.7 & 3.0 & 4.86 & 12.00 \\
\hline 931.15 & $91 X-1,114-116$ & 2.7 & 97.3 & 4.0 & 3.94 & 3.38 \\
\hline
\end{tabular}

Note: Results from wet sieving, carbonate bomb, and SediGraph. Sand $>63$ $\mu \mathrm{m}$; mud $<63 \mu \mathrm{m}$. Median and mode from $<63-\mu \mathrm{m}$ fraction using SediGraph. Carbonate percentage from $<63-\mu \mathrm{m}$ fraction.

The lower marly unit contains a largely planktonic foraminiferal fauna and was deposited on the outer shelf. Its age is Albian-Cenomanian (Belford, 1958). The middle claystone unit lacks calcareous foraminifers, but contains pyritized radiolarians and arenaceous foraminifers. It represents the worldwide anoxic event at the Cenomanian/Turonian boundary, and forms a marker horizon on well logs throughout the north Carnarvon Basin, characterized by gamma-ray and sonic log peaks. The upper marly unit contains planktonic
Table 2. Sedimentological results, Hole 763C.

\begin{tabular}{|c|c|c|c|c|c|c|}
\hline $\begin{array}{l}\text { Depth } \\
\text { (mbsf) }\end{array}$ & $\begin{array}{l}\text { Core, section, } \\
\text { interval }(\mathrm{cm})\end{array}$ & $\begin{array}{l}\text { Sand } \\
(\%)\end{array}$ & $\begin{array}{l}\text { Mud } \\
(\%)\end{array}$ & $\begin{array}{c}\text { Carbonate } \\
(\%)\end{array}$ & $\begin{array}{c}\text { Median } \\
(\mu \mathrm{m})\end{array}$ & $\begin{array}{l}\text { Mode } \\
(\mu \mathrm{m})\end{array}$ \\
\hline & $122-763 C-$ & & & & & \\
\hline 385.53 & $2 \mathrm{R}-1,50-56$ & 12.3 & 87.7 & 43.5 & 0.44 & 2.00 \\
\hline 385.74 & $2 \mathrm{R}-1,73-75$ & 3.6 & 96.4 & 22.0 & 3.25 & 3.86 \\
\hline 385.98 & $2 \mathrm{R}-1,97-99$ & 4.8 & 95.2 & 8.5 & 2.77 & 4.08 \\
\hline 386.12 & $2 \mathrm{R}-1,126-128$ & 16.9 & 83.1 & 67.5 & 2.72 & 3.83 \\
\hline 386.52 & $2 \mathrm{R}-2,1-3$ & 3.2 & 96.8 & 59.0 & 3.08 & 3.86 \\
\hline 386.77 & $2 \mathrm{R}-2,26-28$ & 0.6 & 99.4 & 62.0 & 3.25 & 3.40 \\
\hline 387.01 & $2 \mathrm{R}-2,50-52$ & 0.0 & 100.0 & 40.5 & 2.37 & 3.28 \\
\hline 387.28 & $2 \mathrm{R}-2,76-78$ & 0.0 & 100.0 & 47.5 & 2.55 & 3.36 \\
\hline 387.49 & $2 \mathrm{R}-2,98-100$ & 0.5 & 99.5 & 52.5 & 2.13 & 3.23 \\
\hline 387.78 & $2 \mathrm{R}-2,127-129$ & 1.1 & 98.9 & 42.0 & 1.87 & 2.81 \\
\hline 388.04 & $2 \mathrm{R}-3,3-5$ & 2.2 & 97.8 & 46.0 & 2.25 & 3.09 \\
\hline 388.33 & $2 \mathrm{R}-3,32-34$ & 0.0 & 100.0 & 36.0 & 2.13 & 3.08 \\
\hline 388.50 & $2 \mathrm{R}-3,49-51$ & 1.0 & 99.0 & 43.5 & 2.02 & 3.05 \\
\hline 388.75 & $2 \mathrm{R}-3,75-77$ & 0.2 & 99.8 & 56.0 & 2.34 & 3.32 \\
\hline 389.02 & $2 \mathrm{R}-3,101-103$ & 2.6 & 97.4 & 61.5 & 2.25 & 3.26 \\
\hline 389.32 & $2 \mathrm{R}-3,131-133$ & 0.7 & 99.3 & 46.0 & 1.86 & 3.03 \\
\hline 664.44 & $6 \mathrm{R}-\mathrm{CC}$ & 72.9 & 27.1 & 5.0 & 2.15 & 8.33 \\
\hline 668.60 & 7R-CC & 9.7 & 90.3 & 8.5 & 1.83 & 0.58 \\
\hline 674.96 & $8 \mathrm{R}-\mathrm{CC}$ & 5.4 & 94.6 & 7.0 & 4.65 & 10.44 \\
\hline 684.07 & 9R-CC & 10.8 & 89.2 & 8.5 & 1.38 & 12.04 \\
\hline 698.15 & 11R-CC & 3.8 & 96.2 & 7.0 & 0.64 & 12.60 \\
\hline 707.10 & $12 \mathrm{R}-\mathrm{CC}$ & $67.5^{\mathrm{a}}$ & 32.5 & 6.0 & 0.51 & 2.19 \\
\hline 722.17 & $13 \mathrm{R}-\mathrm{CC}$ & 46.7 & 53.3 & 6.0 & 2.96 & 3.67 \\
\hline 759.73 & 17R-CC & 23.4 & 76.6 & 7.0 & 3.26 & 10.83 \\
\hline 787.38 & 20R-CC & 6.7 & 93.3 & 7.0 & 3.39 & 8.68 \\
\hline 798.51 & $21 \mathrm{R}-\mathrm{CC}$ & 1.3 & 98.7 & 7.0 & 1.88 & 5.01 \\
\hline 808.93 & 22R-CC & 16.3 & 83.7 & 8.5 & 4.88 & 25.67 \\
\hline 814.03 & 23R-CC & 2.3 & 97.7 & 8.5 & 3.08 & 11.60 \\
\hline 827.86 & $24 \mathrm{R}-\mathrm{CC}$ & 2.3 & 97.7 & 7.0 & 2.83 & 9.69 \\
\hline 830.36 & $25 \mathrm{R}-2,125-127$ & 3.7 & 96.3 & 33.0 & 6.42 & 6.49 \\
\hline 832.13 & $25 \mathrm{R}-4,2-4$ & 1.1 & 98.9 & 18.0 & 3.29 & 2.54 \\
\hline 837.31 & $25 \mathrm{R}-\mathrm{CC}$ & $11.6^{\mathrm{a}}$ & 88.4 & 9.5 & 1.97 & 1.30 \\
\hline 840.81 & $26 \mathrm{R}-3,70-72$ & 10.5 & 89.5 & 7.0 & 2.18 & 2.19 \\
\hline 845.93 & $26 \mathrm{R}-\mathrm{CC}$ & 0.0 & 100.0 & 7.0 & 1.67 & 4.03 \\
\hline 857.51 & $28 \mathrm{R}-1,140-142$ & 1.1 & 98.9 & 8.5 & 3.73 & 10.79 \\
\hline 864.86 & $28 \mathrm{R}-6,125-127$ & 3.8 & 96.2 & 8.5 & 5.04 & 10.06 \\
\hline 864.95 & 28R-CC & 4.7 & 95.3 & 4.5 & 3.35 & 3.90 \\
\hline 871.70 & $29 \mathrm{R}-5,9-12$ & $12.3^{\mathrm{a}}$ & 87.7 & 7.0 & 2.79 & 10.09 \\
\hline 873.76 & $29 \mathrm{R}-\mathrm{CC}$ & 2.5 & 97.5 & 7.0 & 2.97 & 9.77 \\
\hline 883.88 & 30R-CC & 3.3 & 96.7 & 7.0 & 2.61 & 9.72 \\
\hline 894.50 & 31R-CC & 0.7 & 99.3 & 8.5 & 2.75 & 10.36 \\
\hline 903.64 & $32 \mathrm{R}-\mathrm{CC}$ & 5.3 & 94.7 & 4.5 & 3.37 & 4.14 \\
\hline 907.87 & $33 \mathrm{R}-3,126-$ & 2.7 & 97.3 & 7.0 & 4.83 & 12.12 \\
\hline 909.87 & 33R-CC & 2.5 & 97.5 & 7.0 & 3.43 & 9.03 \\
\hline 921.85 & $34 \mathrm{R}-\mathrm{CC}$ & 4.5 & 95.5 & 8.5 & 4.05 & 4.86 \\
\hline 933.08 & $36 \mathrm{R}-1,98-99$ & 3.5 & 96.5 & 8.5 & 3.00 & 3.72 \\
\hline 938.19 & $36 \mathrm{R}-5,9-10$ & 6.0 & 94.0 & 7.0 & 2.98 & 10.36 \\
\hline 940.10 & 36R-CC & 4.1 & 95.9 & 8.5 & 1.88 & 10.54 \\
\hline 951.72 & 37R-CC & 4.9 & 95.10 & 8.50 & 3.73 & 3.79 \\
\hline 960.95 & 38R-CC & 2.3 & 97.70 & 7.00 & 3.09 & 3.95 \\
\hline 971.87 & $40 \mathrm{R}-2,8-10$ & $6.8^{\mathrm{a}}$ & 93.20 & 7.00 & 3.95 & 10.11 \\
\hline 986.91 & $41 \mathrm{R}-5,130-132$ & $10.8^{\mathrm{a}}$ & 89.20 & 7.00 & 3.32 & 9.89 \\
\hline 996.31 & $42 R-5,120-123$ & $37.3^{\mathrm{a}}$ & 62.70 & 8.50 & 2.72 & 9.16 \\
\hline 1012.03 & $44 \mathrm{R}-3,86-89$ & 2.8 & 97.20 & 8.50 & 2.76 & 2.08 \\
\hline 1027.45 & 45R-CC & 8.7 & 91.30 & 7.00 & 3.01 & 4.04 \\
\hline 1033.10 & 46R-CC & 2.6 & 97.40 & 7.00 & 1.59 & 3.70 \\
\hline
\end{tabular}

Note: See Table 1 for explanation of data.

Includes some unbroken grains of matrix claystone.

foraminifers of Turonian and Coniacian age, and was deposited on the outer shelf and upper slope.

\section{Toolonga Calcilutite}

The Toolonga Calcilutite rests conformably on the Haycock Marl at Sites 762 and 763, as it does in most of the Dampier Sub-basin. Elsewhere it is disconformable on older sediments. The type section $\left(27^{\circ} 35.5^{\prime} \mathrm{S}, 114^{\circ} 10.5^{\prime} \mathrm{E}\right)$ is near Yalthoo Bore on Murchison House Station, and an offshore reference section is in Goodwyn No. 6 well on the Rankin Platform (near Goodwyn No. 1 well on Fig. 1), between 2602 $\mathrm{m}$ and $2642 \mathrm{~m}$. Offshore the formation is about $70 \mathrm{~m}$ thick on the Rankin Platform and much thicker in some areas. It is 
Table 3. Composition of detrital mineral grains in coarse fraction in Barrow Group and Muderong Shale, Hole 763C.

\begin{tabular}{|c|c|c|c|c|c|c|c|c|c|c|c|}
\hline $\begin{array}{l}\text { Depth } \\
\text { (mbsf) }\end{array}$ & $\begin{array}{l}\text { Core, section, } \\
\text { interval }(\mathrm{cm})\end{array}$ & $\begin{array}{c}\text { Monocrystalline } \\
\text { quartz } \\
\text { grains }\end{array}$ & $\begin{array}{l}\text { Polycrystalline } \\
\text { quartz } \\
\text { grains }\end{array}$ & $\begin{array}{c}\text { Plagioclase } \\
\text { feldspar } \\
\text { grains }\end{array}$ & $\begin{array}{l}\text { Potash } \\
\text { feldspar } \\
\text { grains }\end{array}$ & $\begin{array}{l}\text { Sedimentary } \\
\text { lithic } \\
\text { fragments }\end{array}$ & $\begin{array}{l}\text { Volcanic } \\
\text { lithic } \\
\text { fragments }\end{array}$ & $\begin{array}{l}\text { Total } \\
\text { quartz } \\
\text { grains }\end{array}$ & $\begin{array}{c}\text { Total } \\
\text { lithic } \\
\text { fragments }\end{array}$ & $\begin{array}{l}\text { Total } \\
\text { feldspar } \\
\text { grains }\end{array}$ & Glauconite \\
\hline & $122-763 C-$ & & & & & & & & & & \\
\hline 610.02 & $46 \mathrm{X}-2,51-53$ & 48.2 & 5.6 & 18.8 & 1.5 & 25.9 & 0 & 53.8 & 31.5 & 20.3 & 34.3 \\
\hline 621.00 & $47 X-3,49-51$ & 63.4 & 4.6 & 20.9 & 5.2 & 5.2 & 0.7 & 68.0 & 10.5 & 26.1 & 23.5 \\
\hline 664.44 & $6 \mathrm{R}-\mathrm{CC}$ & 78.6 & 2.7 & 12.0 & 5.7 & 1.0 & 0 & 81.3 & 3.7 & 17.7 & 0.3 \\
\hline 668.60 & 7R-CC & 74.2 & 4.1 & 13.2 & 8.1 & 0.3 & 0 & 78.3 & 4.4 & 21.3 & 1.7 \\
\hline 674.90 & $8 \mathrm{R}-\mathrm{CC}$ & 76.8 & 7.4 & 10.8 & 4.7 & 0 & 0.3 & 84.3 & 7.7 & 15.5 & 1.0 \\
\hline 684.07 & 9R-CC & 80.7 & 4.1 & 9.8 & 5.1 & 0.3 & 0 & 84.8 & 4.4 & 14.9 & 1.7 \\
\hline 698.15 & 11R-CC & 80.1 & 5.3 & 9.2 & 5.3 & 0 & 0 & 85.4 & 5.3 & 14.5 & 31.4 \\
\hline 707.10 & 12R-CC & 71.1 & 3.1 & 19.0 & 6.5 & 0.3 & 0 & 74.2 & 3.4 & 25.5 & 2.0 \\
\hline 722.17 & 13R-CC & 90.7 & 0.7 & 4.8 & 3.4 & 0.3 & 0 & 91.4 & 1.0 & 8.2 & 3.0 \\
\hline 759.73 & 17R-CC & 74.8 & 3.7 & 14.8 & 6.4 & 0.3 & 0 & 78.5 & 4.0 & 21.2 & 0.7 \\
\hline 787.38 & 20R-CC & 71.2 & 4.4 & 18.0 & 5.4 & 1.0 & 0 & 75.6 & 5.4 & 23.4 & 1.7 \\
\hline 798.51 & 21R-CC & 61.8 & 3.8 & 23.3 & 10.4 & 0.7 & 0 & 65.6 & 4.5 & 33.7 & 4.0 \\
\hline 808.93 & 22R-CC & 74.5 & 2.0 & 12.9 & 10.5 & 0 & 0 & 76.5 & 2.0 & 23.4 & 2.0 \\
\hline 814.03 & 23R-CC & 67.0 & 6.6 & 20.0 & 5.9 & 0.4 & 0 & 73.6 & 7.0 & 25.9 & 10.0 \\
\hline 827.86 & $24 \mathrm{R}-\mathrm{CC}$ & 76.9 & 2.8 & 13.3 & 7.0 & 0 & 0 & 79.7 & 2.8 & 14.0 & 4.7 \\
\hline 830.36 & $25 \mathrm{R}-2,125-127$ & 84.8 & 0 & 12.1 & 3.0 & 0 & 0 & 84.8 & 0 & 15.1 & 1.0 \\
\hline 832.13 & $25 \mathrm{R}-4,2-4$ & 70.7 & 2.0 & 18.7 & 8.6 & 0 & 0 & 72.7 & 2.0 & 27.3 & 1.0 \\
\hline 837.31 & $25 \mathrm{R}-\mathrm{CC}$ & 71.4 & 1.0 & 18.1 & 9.5 & 0 & 0 & 72.4 & 1.0 & 27.6 & 0.5 \\
\hline 840.81 & $26 \mathrm{R}-3,70-72$ & 77.5 & 3.8 & 13.5 & 5.2 & 0 & 0 & 81.3 & 3.8 & 18.7 & 3.7 \\
\hline 857.51 & $28 \mathrm{R}-1,140-142$ & 78.3 & 2.4 & 12.4 & 6.9 & 0 & 0 & 80.7 & 2.4 & 19.3 & 3.0 \\
\hline 864.86 & $28 \mathrm{R}-6,125-127$ & 77.1 & 1.0 & 12.3 & 9.6 & 0 & 0 & 78.1 & 1.0 & 21.9 & 2.3 \\
\hline 864.95 & 28R-CC & 75.3 & 1.4 & 16.1 & 7.2 & 0 & 0 & 76.7 & 1.4 & 23.3 & 2.7 \\
\hline 871.70 & $29 R-5,9-12$ & 77.3 & 1.0 & 11.1 & 10.6 & 0 & 0 & 78.3 & 1.0 & 21.7 & 1.0 \\
\hline 873.76 & 29R-CC & 74.9 & 2.1 & 15.7 & 6.8 & 0.5 & 0 & 77.0 & 2.6 & 22.5 & 4.5 \\
\hline 883.88 & 30R-CC & 72.7 & 4.5 & 14.5 & 7.6 & 0.7 & 0 & 77.2 & 4.5 & 22.1 & 3.7 \\
\hline 894.50 & 31R-CC & 73.7 & 2.9 & 13.9 & 7.7 & 1.9 & 0 & 76.6 & 4.8 & 21.6 & 0.5 \\
\hline 903.64 & $32 \mathrm{R}-\mathrm{CC}$ & 70.5 & 2.2 & 20.0 & 4.5 & 1.8 & 0 & 72.7 & 4.0 & 25.5 & 2.6 \\
\hline 907.87 & $33 \mathrm{R}-3,126-128$ & 66.5 & 3.9 & 18.1 & 10.7 & 0.7 & 0 & 70.4 & 4.6 & 28.8 & 6.3 \\
\hline 909.75 & $33 \mathrm{R}-\mathrm{CC}$ & 80.0 & 2.6 & 13.7 & 3.2 & 0.5 & 0 & 82.6 & 3.1 & 16.9 & 5.0 \\
\hline 921.85 & $34 \mathrm{R}-\mathrm{CC}$ & 63.9 & 4.2 & 17.8 & 8.9 & 5.2 & 0 & 68.1 & 9.4 & 26.7 & 4.5 \\
\hline 933.08 & $36 \mathrm{R}-1,98-99$ & 77.8 & 6.1 & 9.4 & 6.1 & 0.7 & 0 & 83.9 & 6.8 & 15.5 & 1.0 \\
\hline 938.19 & $36 \mathrm{R}-5,9-10$ & 78.3 & 4.1 & 13.8 & 3.1 & 0.7 & 0 & 82.4 & 4.8 & 16.9 & 3.0 \\
\hline 940.70 & $36 \mathrm{R}-\mathrm{CC}$ & 77.5 & 4.2 & 9.0 & 9.0 & 0.3 & 0 & 81.7 & 4.5 & 18.0 & 3.7 \\
\hline 951.12 & 37R-CC & 82.7 & 2.7 & 10.8 & 3.7 & 0 & 0 & 85.4 & 2.7 & 14.5 & 1.7 \\
\hline 960.95 & 38R-CC & 84.6 & 2.8 & 8.4 & 3.8 & 0.3 & 0 & 87.4 & 3.1 & 12.2 & 4.7 \\
\hline 971.87 & $40 \mathrm{R}-2,26-28$ & 70.5 & 4.1 & 14.7 & 9.9 & 0.7 & 0 & 74.6 & 4.8 & 24.6 & 2.7 \\
\hline 986.91 & $41 R-5,130-132$ & 79.3 & 2.8 & 8.3 & 8.6 & 1.0 & 0 & 82.1 & 3.8 & 16.9 & 3.3 \\
\hline 996.31 & $42 R-5,120-123$ & 75.1 & 5.3 & 10.9 & 8.8 & 0 & 0 & 80.4 & 5.3 & 19.7 & 5.0 \\
\hline 1012.03 & $44 \mathrm{R}-3,92-95$ & 76.5 & 3.4 & 10.9 & 8.9 & 0.3 & 0 & 79.9 & 3.7 & 19.8 & 2.3 \\
\hline 1027.45 & $45 \mathrm{R}-\mathrm{CC}$ & 83.7 & 2.8 & 6.6 & 6.9 & 0 & 0 & 86.5 & 2.8 & 13.5 & 3.7 \\
\hline 1033.10 & 46R-CC & 76.6 & 5.9 & 7.2 & 10.3 & 0 & 0 & 82.5 & 5.9 & 17.5 & 3.3 \\
\hline
\end{tabular}

Note: Composition of sieved coarse fraction $(>63 \mu \mathrm{m})$ of Neocomian sediments normalized to $100 \%$, except for glauconite grains. Percentages of the glauconite grains are relative to the other component grains per thin section. Relative percentages of grains were determined by point-counting 200 to 300 grains per thin section. The Gazzi-Dickinson point-counting method was used for minimizing the compositional effects of grain size.

identified in wells by low values in gamma-ray and sonic logs. The Toolonga Calcilutite consists largely of planktonic foraminifers and nannofossils, with occasional traces of pyrite and glauconite. The formation also contains bivalves (especially Inoceramus), brachiopods (in shallower water), ostracodes, bryozoans, crinoids, serpulids, and sponges. In the south Carnarvon Basin its age is Santonian to Campanian (Belford, 1958). In the Dampier Sub-basin it is generally of Santonian age (Heath and Apthorpe: pers. comm. quoted in Hocking et al., 1987).

\section{CENTRAL EXMOUTH PLATEAU CRETACEOUS SEQUENCES}

The results from Sites 762 and 763 provide more detail of Cretaceous strata and fauna than was previously available from the petroleum exploration wells on the Exmouth Plateau. These wells depended on cuttings and some sidewall cores for samples, but were more completely wireline logged than the ODP holes. Because Site $762\left(19^{\circ} 53.23^{\prime} \mathrm{S}, 112^{\circ} 115.24^{\prime} \mathrm{E}\right)$ is very close to Esso Eendracht No. 1 well $\left(19^{\circ} 54.48^{\prime} \mathrm{S}\right.$, $\left.112^{\circ} 14.59^{\prime} \mathrm{E}\right)$, and $763\left(20^{\circ} 35.20^{\prime} \mathrm{S}, 112^{\circ} 12.50^{\prime} \mathrm{E}\right)$ is very close to Esso Vinck No. 1 well $\left(20^{\circ} 35.07^{\prime} \mathrm{S}, 112^{\circ} 11.57^{\prime} \mathrm{E}\right)$, information from the two pairs of wells (each pair sharing the same structural position) can be combined (e.g., Fig. 2).
Summary logs of the Cretaceous sequence at Sites 762 and 763 are provided in Figures 4 and 5, which relate lithological and wireline logs to age zones, lithostratigraphic units, stratigraphic names, and key sediment components. More detailed lithostratigraphic logs with paleoenvironmental interpretations are shown in Haq, von Rad, O'Connell, et al. (1990, back-pocket figs. $2 \mathrm{D}$ and $2 \mathrm{E}$ ) and in Haq et al. (this volume, their figs. 6 and 7). These diagrams clearly illustrate major changes in sediment type at the top of the Barrow Group, within the Muderong-Gearle-Haycock-Toolonga sequence, and at the top of the Toolonga sequence. There are marked differences in sediment thickness and character between the two ODP sites, which are about $80 \mathrm{~km}$ apart and in almost identical water depths (1371 $\mathrm{m}$ and $1379 \mathrm{~m})$. The gross differences between the two sites are illustrated in the seismic profile connecting the two sites (Fig. 3), which shows clear thinning northward in the Berriasian to Cenomanian sequences, and thickening northward in the Turonian to Maestrichtian and Paleogene sequences.

The grain size and carbonate percentage diagrams (Figs. 6 and 7), derived from Tables 1 and 2, also help illustrate the changes through the sequences, despite the less-than-optimum number of the samples and despite recovery problems in 


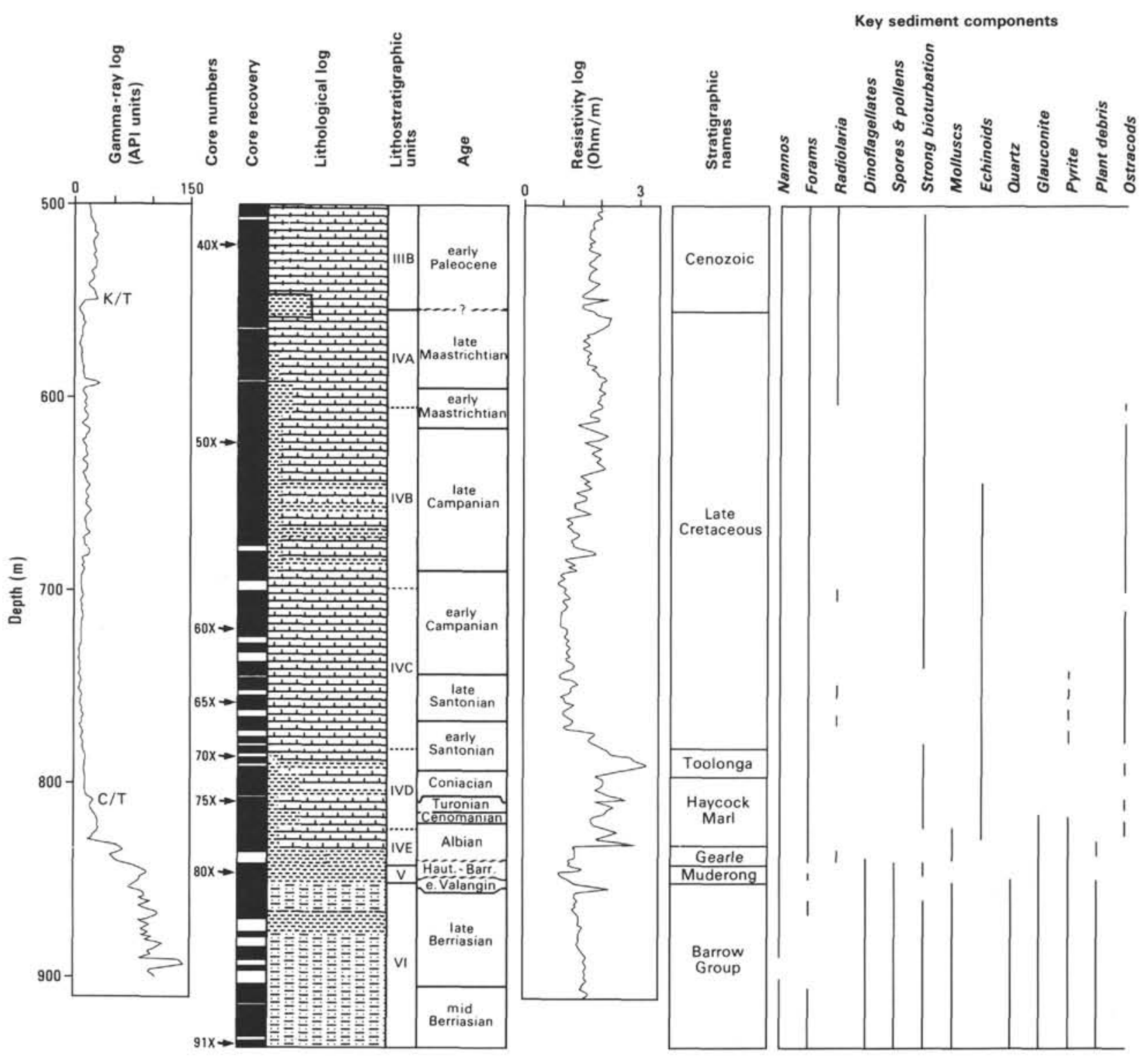

Figure 4. Lithological and wireline logs of Site 762, showing lithostratigraphic units and stratigraphic names (after Hocking et al., 1987). Key sediment components are taken from our coarse fraction studies, paleontological and sedimentological results in Haq, von Rad, O'Connell, et al. (1990), and paleontological results in Brenner (this volume, chapter 31) and Damotte (this volume). Water depth is $1371 \mathrm{~m}$.

sandy sequences. In Hole 762C (Fig. 6) grain size remains fairly constant in the pelagic carbonates (Haycock Marl and younger), decreases in the shelf mudstones (Gearle and $\mathrm{Mu}$ derong), and is variable in the prodelta mudstones and sandstones (Barrow Group). The sand fraction depends on foraminiferal content in the pelagic carbonates; it is detrital and variable in volume in the shelf mudstones and highly variable in the prodelta sediments. Carbonate content is high in the pelagic carbonates, variable in the shelf mudstone and marl sequences (Muderong-Gearle-Haycock), and very low in the prodelta sediments. In Hole $763 \mathrm{C}$ only the prodelta sediments of the Barrow Group were sampled (Fig. 7), and these show considerable variation in grain size and sand content and the influence of occasional carbonate-rich turbidites in the carbonate content.

Displays of typical grain-size curves for the finer fractions $(<63 \mu \mathrm{m})$ from the two ODP holes (Figs. 8 and 9), again derived from Tables 1 and 2 , illustrate the marked differences between pelagic carbonates, shelf mudstones, and prodelta mudstones. The pelagic carbonates (Fig. 8) form almost symmetrical unimodal curves which do not change greatly with age. Their peaks lie at $2-4 \mu \mathrm{m}$ on the clay-silt boundary. The prodelta Berriasian mudstones (Fig. 9) are also unimodal, but they are skewed toward coarser grain sizes, and their peaks $(10-12 \mu \mathrm{m})$ lie in the fine silt range. An Aptian shelf mudstone appears to be a mix of several components, and has a major peak in the clay range $(2 \mu \mathrm{m})$ and another in the fine silt range $(10 \mu \mathrm{m})$.

A quantitative microscope study of detrital grains in the lower part of Hole 763 enabled the major components of the coarse fraction to be separated out (Table 3 ). The sequence covered is the lower part of the Muderong Shale and the Barrow Group from 622.5 to 1036.6 mbsf. The results show the percentages of total quartz, total lithic, total feldspar, and 


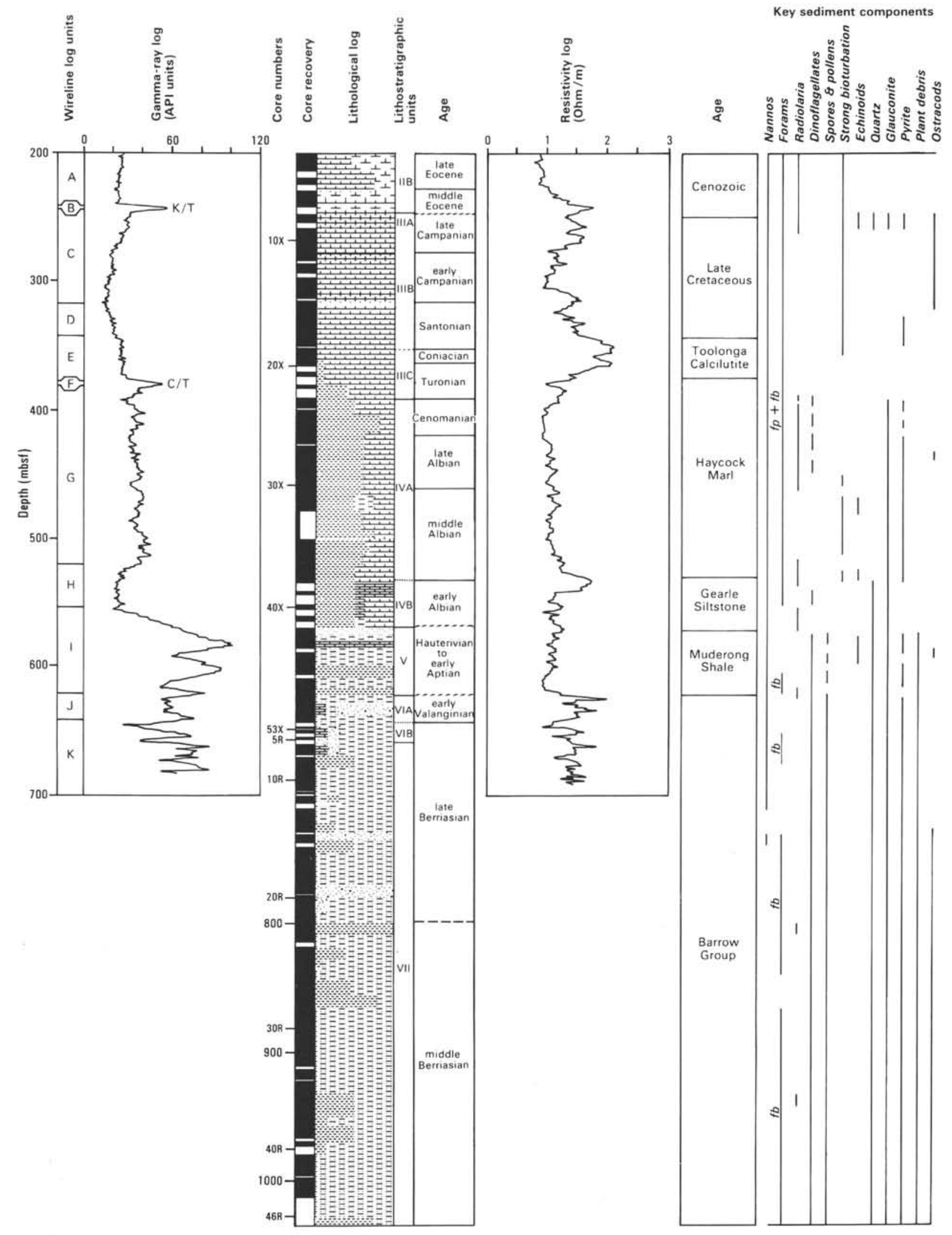

Figure 5. Lithological and wireline logs of Site 763, showing lithostratigraphic units and stratigraphic names (after Hocking et al., 1987). Key sediment components are taken from our coarse fraction studies, paleontological and sedimentological results in Haq, von Rad, O'Connell, et al. (1990), and paleontological results in Brenner (this volume, chapter 31) and Damotte (this volume). Water depth is $1379 \mathrm{~m}$. 

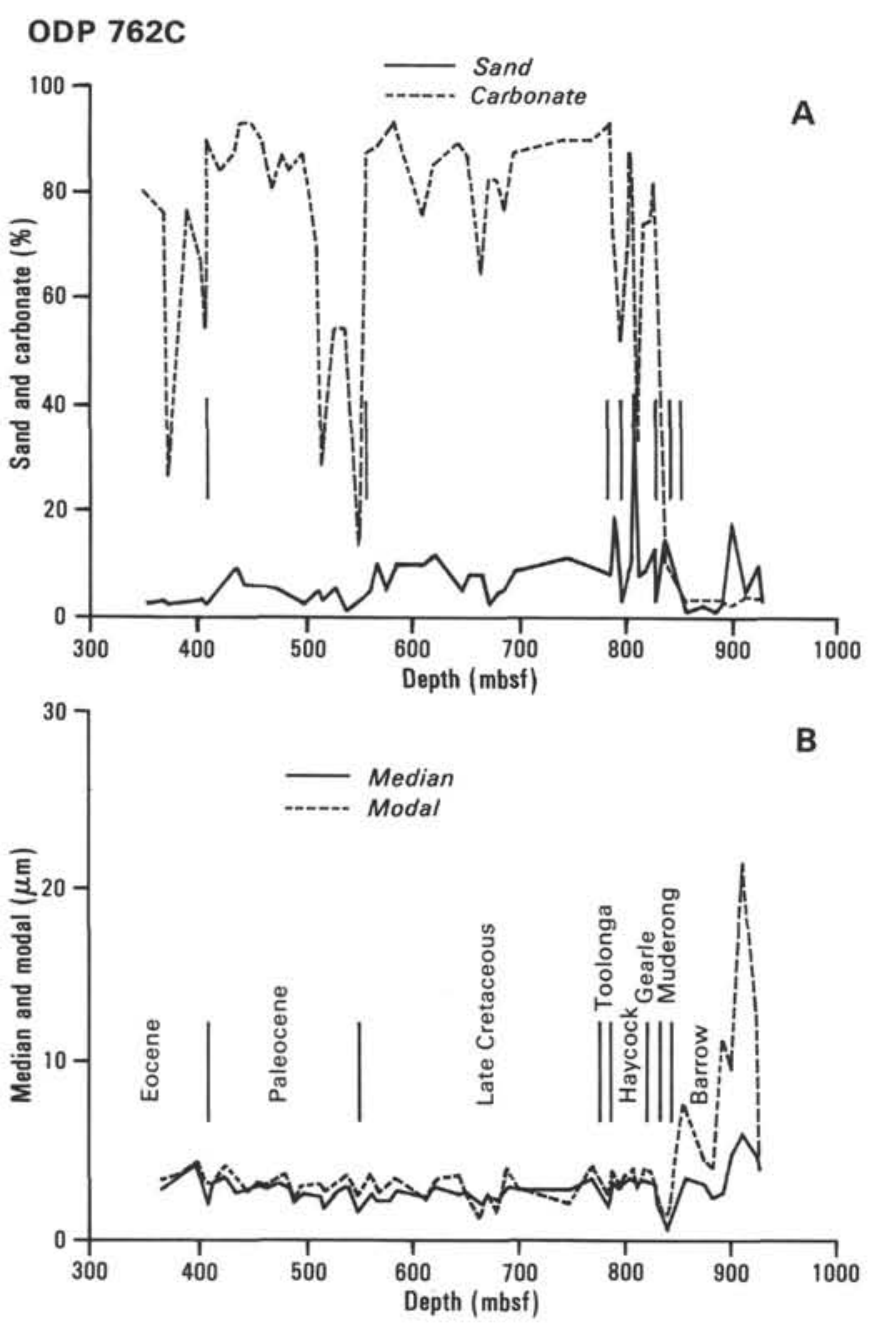

Figure 6. Grain size and carbonate percentage information for Hole $762 \mathrm{C}$. Percentages of sand are in total sediment; all other values are in fraction finer than $63 \mu \mathrm{m}$. A. Note changes in sand and carbonate percentages at top of Barrow Group, top of Haycock Marl, and in lower Paleocene and lower Eocene. B. Note major decrease in grain size in the fine fraction at the top of the Barrow Group.

glauconite in the coarse fraction, and also subsets of these (e.g., monocrystalline quartz and polycrystalline quartz). The feldspars were not stained, so the distinction between plagioclase and potash feldspar is not very strong quantitatively. In general, quartz is dominant over feldspar and glauconite, lithic grains are relatively unimportant, monocrystalline quartz is the dominant quartz form, and plagioclase feldspar dominates over potash feldspar.

For the sake of comparison we will describe the various sedimentary sequences using the stratigraphic intervals described briefly under the "Regional Cretaceous Geology" section (this chapter), referring also to the shipboard lithostratigraphic, seismic, and well-log units (Haq, von Rad, O'Connell, et al., 1990) correlated in Figures 3, 4, 5, and 10. Figure 10 also shows the global relative change of coastal onlap, and the third-order eustatic cycle nomenclature of Haq et al. (1988), to allow comparison of these features with those visible in the local sedimentary packages. The detailed seismic stratigraphy of an area of the Exmouth Plateau which includes Sites 762 and 763 has been described on selected seismic lines by Erskine and Vail (1988) and Boyd et al. (this volume), and
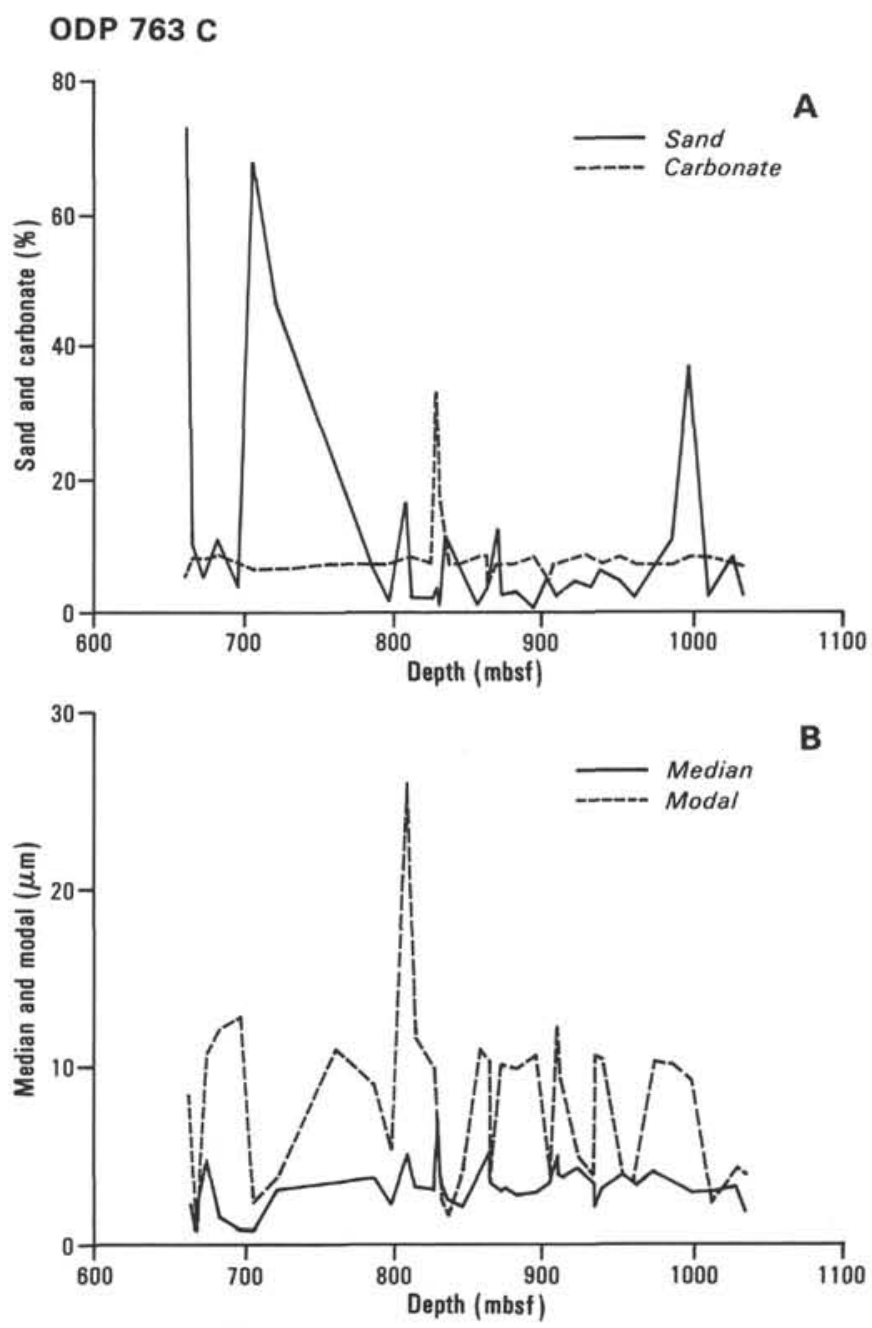

Figure 7. Grain size and carbonate percentage information for Barrow Group in Hole $763 \mathrm{C}$, within prodelta sequence of mudstone and interbedded turbidite sandstones. Percentages of sand are in total sediment; all other values are in fraction finer than $63 \mu \mathrm{m}$. A. Carbonate makes up less than $5 \%$ of the fine fraction. The total sand content varies greatly, from less than $5 \%$ in mudstones, to more than $70 \%$ in some sandstones. B. Median diameter of the fine fraction is about 3-4 $\mu \mathrm{m}$, with modal diameter about $10 \mu \mathrm{m}$.

we do not intend to cover this aspect of the well results in this paper. However, we will make use of their studies, the more regional seismic study of the western Exmouth Plateau by Exon and Buffler (this volume), and the wireline log study of Boyd and Bent (this volume), as appropriate in the unit descriptions.

In general, the history of sedimentation in the Cretaceous sequences of the western Exmouth Plateau shows the effect of declining detrital input and deepening water depths with time. A flood of deltaic material came from the south and possibly the east in the Berriasian (Exon and Willcox, 1978; Veevers and Powell, 1979; Boyd et al., this volume; Exon and Buffler, this volume). This was cut off in the Valanginian when Greater India separated from the Exmouth Plateau to form the Gascoyne and Cuvier abyssal plains (Fullerton et al., 1989). Thereafter, detrital influx could come only from the east and, as the detrital hinterlands were lowered, providing less detritus with time, the plateau sank, and pelagic carbonate sedimentation became dominant. Decompacted sedimentation 


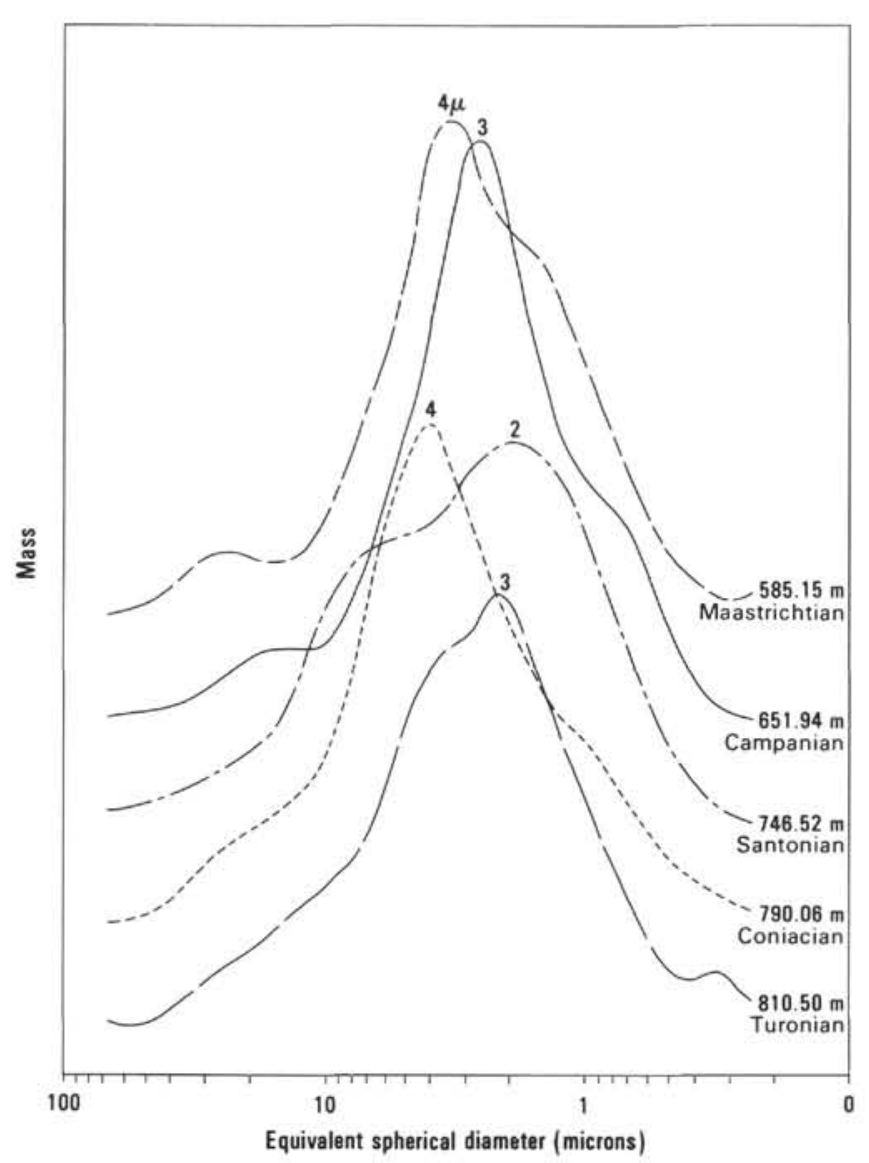

Figure 8. Landscaped grain-size curves of typical Upper Cretaceous chalks from Site 762 , from a SediGraph using the $<63-\mu \mathrm{m}$ fraction (i.e., the entire sediment excluding foraminifers). The curves show mass plotted against equivalent spherical diameter and illustrate the unimodal character of nannofossil chalks, with peaks at 2-4 $\mu \mathrm{m}$, a coarse tail extending to $20 \mu \mathrm{m}$, and a fine tail to $0.3 \mu \mathrm{m}$.

rates fell, particularly at Site 763 where the Berriasian delta was well developed, from nearly $30 \mathrm{~cm}$ per thousand years (k.y.) in the Berriasian, to an average of $2 \mathrm{~cm}$ in the rest of the Early Cretaceous, and $1 \mathrm{~cm}$ in the Late Cretaceous (O'Brien and Manghnani, this volume).

In this section, we make extensive use of the shipboard paleontological determinations from Leg 122 (Haq, von Rad, O'Connell, et al., 1990) and Brenner (this volume, chapter 31), but for the sake of brevity do not continuously refer to the sources. We also use the semiquantitative X-ray analyses of Wilkens et al. (this volume) without referring back to the authors. We thank both groups for their valuable data. All ages quoted are for the Haq et al. $(1987,1988)$ time scale.

\section{Barrow Group}

\section{Site 763}

(622.5-1036.6 mbsf, Units VI and VII, Cores 122-763B$48 \mathrm{X}$ to $122-763 \mathrm{C}-46 \mathrm{R})$

The Barrow Group is relatively thick in the area of Site 763. At the nearby Vinck No. 1 well it is $677 \mathrm{~m}$ thick; the upper 414 $\mathrm{m}$ was penetrated at Site 763 (Fig. 5). In Vinck well the group lies within four microplankton zones, Kalyptea wisemaniae to Egmontodinium torynum (i.e., spanning the earliest Berriasian to earliest Valanginian) (Brenner, this volume, chapter

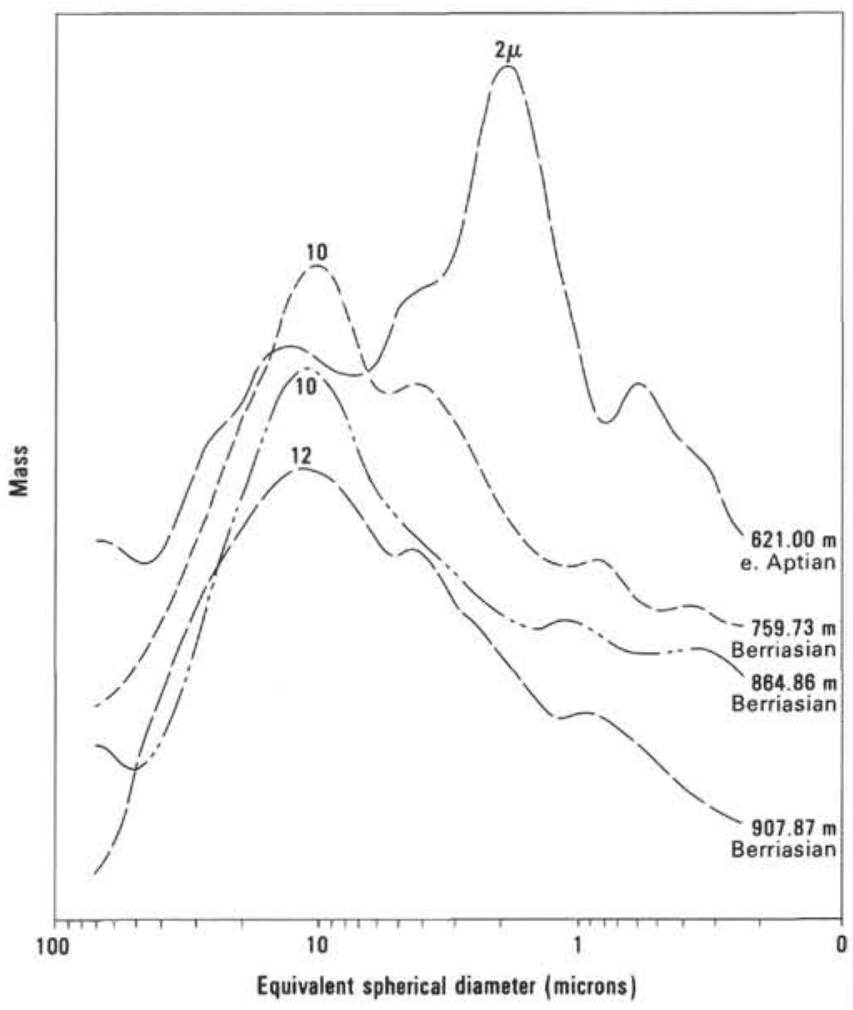

Figure 9. Landscaped grain-size curves (as in Fig. 8) from Site 763, of Berriasian prodelta mudstone and early Aptian marine claystone. The Berriasian mudstone curves are unimodal and show peaks at 10-12 $\mu \mathrm{m}$, coarse tails to $50 \mu \mathrm{m}$, and fine tails to $0.3 \mu \mathrm{m}$. The Aptian claystone forms a more complex curve, suggesting a mixed origin, with a peak at $2 \mu \mathrm{m}$, a subsidiary peak at $10 \mu \mathrm{m}$, a coarse tail extending to $30 \mu \mathrm{m}$, and a fine tail to $0.2 \mu \mathrm{m}$.

31; Helby et al., 1987), a period of about 6 million years (m.y.). The lowest part of Site 763 is within the Cassiculosphaeridia delicata zone, of middle Berriasian age.

The lowermost lithostratigraphic unit, Unit VII, is $376 \mathrm{~m}$ thick at Site 763 (Cores $122-763$ C-5R to $-46 R$; 660.6-1036.6 mbsf). It consists largely of remarkably uniform, almost noncalcareous, very dark claystone with silt, grading to sandy silty claystone (PI. 1, Fig. 1). The organic carbon content is generally in the range $0.6 \%-1.0 \%$, with some values as low as $0.3 \%$ and as high as $1.9 \%$. Bedding is massive to weakly laminated, and bioturbation is fairly common (Pl. 1, Fig. 1). Fecal pellets are common. Carbonate cemented, turbiditic quartz sandstones up to $55 \mathrm{~cm}$ thick (some containing glauconite pellets) make up about $10 \%$ of the upper $125 \mathrm{~m}$ of this unit, but are rarely present deeper (PI. 1, Fig. 2; Pl. 2, Fig 1). They show both normal and reverse grading. In the upper 60 $m$ of the unit the quartz grains include extremely well-rounded coarse grains and angular fine grains. The angular material is reddish-stained quartz, probably derived from an arid terrain. In the remainder of the unit, quartz is colorless, fine-grained and subangular. Microscopic examination indicates the few feldspars are albite and orthoclase. Muscovite occurs sporadically.

Two thin bentonite layers, $10 \mathrm{~cm}$ thick, occur in the middle of the unit ( 842.9 mbsf and $862.15 \mathrm{mbsf}$ ). Von Rad and Thurow (this volume) regard these montmorillonitic bentonites as part of widespread deposition of dacitic to rhyolitic ash layers, derived from a number of vents around the Exmouth Plateau related to the breakup of Gondwanaland. 


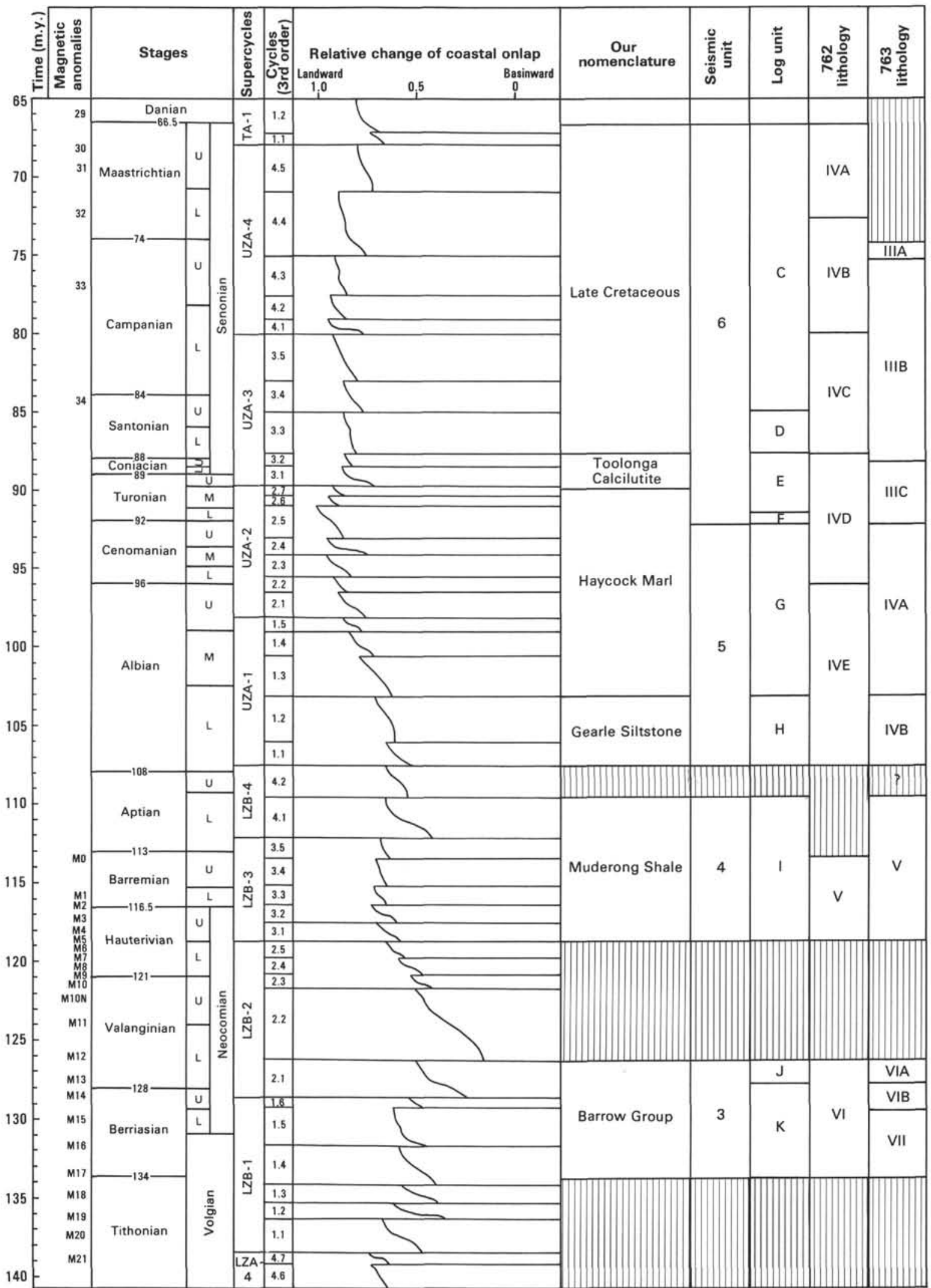

Figure 10. Time stratigraphic diagram showing relationship of Cretaceous lithostratigraphic units drilled at Sites 762 and 763 to seismic units (Haq, von Rad, O'Connell, et al., 1990) and log units (Boyd and Bent, this volume). Ages and global relative change of coastal onlap after Haq et al. (1988). 
Unit VII (Fig. 5) contains a few nannofossils near the top, benthic foraminifers (Jones and Wonders, this volume), rare radiolarians, abundant dinoflagellates, spores and pollen, quartz, glauconite, pyrite, and plant debris. The dinoflagellate zones identified are Batioladinium reticulatum, Dissimulidinium lobispinosum, and Cassiculosphaeridia delicata varying from early middle to late Berriasian (Brenner, this volume, chapter 31). In addition there are some sequences with belemnites, ostracodes, rare ammonites and bivalves, and especially disseminated shell debris. Large, early diagenetic pyrite and siderite nodules occur at various levels (PI. 2, Fig. 1; PI. 2, Fig. 2). Pyrite and siderite also occur as concretions and burrow fillings. Pyrite and glauconite also commonly occur as casts of shelly fossils. Semiquantitative X-ray studies show pyrite throughout, with siderite present below $735 \mathrm{mbsf}$ and abundant below 898 mbsf. They also show that these finegrained sediments are dominantly quartz and clay; calcite-rich beds are common above 800 mbsf. Kaolinite generally predominates over illite and siderite, but below 960 mbsf there are abundant smectites which probably represent bentonite horizons.

The middle unit, Unit VIB, is $23.6 \mathrm{~m}$ thick (Cores 122 $763 \mathrm{~B}-50 \mathrm{X}$ to $122-763 \mathrm{C}-5 \mathrm{R}$; $637.0-660.6 \mathrm{mbsf}$ ). The organic carbon content is $0.5 \%-1.0 \%$. The unit consists of dark gray silty claystone to sandy silty claystone, carbonate-cemented quartz sandstone (sometimes containing glauconite pellets), and recrystallized limestone containing glauconite pellets. Recovery is poor and the wireline logs (Figs. 5 and 11) suggest that, in reality, sandstones and lesser limestones make up more than half the sequence although they were not recovered. Those quartz sandstones that were recovered are graded, suggesting a turbidite origin in a deep-water fan.

As indicated in Figure 5, nannofossils, dinoflagellates, spores and pollen, quartz, glauconite, pyrite, and plant debris are all present in Unit VIB; some beds contain shelly detritus. Dinoflagellates belong to the $B$. reticulatum zone of late Berriasian age (Brenner, this volume, chapter 31). Semiquantitative X-ray examination indicates that quartz is generally dominant, with clay subdominant; however, in some samples calcite makes up nearly half the sediment. Smectite, illite, and kaolinite are all present in the clay fraction, and zeolites are abundant.

The upper unit, Unit VIA, is a condensed section $14.5 \mathrm{~m}$ thick (Cores $122-763 \mathrm{~B}-48 \mathrm{X}$ to $-50 \mathrm{X} ; 622.5-637.0 \mathrm{~m}$ ). It consists of dark silty claystone to sandy siltstone, with recrystallized limestone in three beds up to $50 \mathrm{~cm}$ thick. The organic carbon content varies from $0.4 \%$ to $1.8 \%$. The lack of variation in the wireline logs (Fig. 11) corroborates the evidence from the high core recovery that there is little bulk variation in the unit. Belemnites, sand-sized glauconite pellets, and disseminated pyrite are common; the belemnites decrease in abundance downward. Nannofossils, dinoflagellates, spores and pollen, quartz, and plant debris are common (Fig. 5). The unit contains dinoflagellates of the $E$. torynum and $B$. reticulatum zones, and probably spans the Berriasian-Valanginian boundary (Brenner, this volume, chapter 31). Semiquantitative X-ray examination indicates that quartz, clay, and calcite are all important constituents; kaolinite is the dominant clay but there is intermittent illite; pyrite is present but siderite absent.

The coarse fraction studies detailed in Table 3 shed more light on the nature of the Barrow Group in Hole 763C. When they are plotted on a triangular diagram of total quartz, feldspar, and lithic grains (Fig. 12), they show the clear dominance of quartz. The subdivisions of the diagram are those employed by Dickinson (1985) to characterize provenance. His interpretation, from a study of many sandstone suites, would be that such sand grains come from continental block provenances, with sources on stable cratons and in uplifted basement; the more feldspathic sands would come from uplifted basement along rift shoulders on transform ruptures. Another triangular plot, of monocrystalline quartz, feldspar, and lithic grains (not illustrated in this paper) is very similar and can be interpreted similarly.

This interpretation from Dickinson (1985) points to ultimate derivation from the Pilbara Block, and perhaps from basement areas to the south from what later became part of Greater India. However, the Cretaceous Barrow Group sediments contain Carboniferous, Permian, and Triassic spores and pollen (R. Helby, pers. comm., 1990; W. Brenner, pers. comm., 1990), suggesting that much of the sand is recycled. One difficulty with the above interpretation is the dominance of plagioclase in the feldspar (Table 3). According to Dickinson, if the coarse fraction is from a craton the more resistant potash feldspar should dominate over plagioclase; reworking should increase this dominance. The dominant plagioclase, which is generally of fresh appearance (although sometimes replaced by carbonate), may have come from rift volcanism, although the paucity of lithic grains then presents a problem. Another possibility is that the plagioclase is diagenetic albite replacing potash feldspar, a process mentioned by Dickinson (1985, p. 337), but the petrological results indicate that this is not the case.

The plagioclase probably is not from syn-depositional Cretaceous volcanics, because of the lack of lithic grains. It is most probably derived from reworked Triassic-Jurassic volcanics, weathering and erosion removing the less-resistant lithic grains. Such volcanics form a broad belt along the rifted western Exmouth Plateau and formed islands that were being eroded in the Neocomian (Exon and Buffler, this volume). Overall, we suggest that the detrital sand grains in the Barrow Group are of polygenetic origin-coming from continental basement, reworked Paleozoic sedimentary rocks, and Triassic-Jurassic rift volcanics.

A plot of quartz and glauconite content against depth, also derived from Table 3 (Fig. 13), gives additional information about Barrow Group deposition. Glauconite being diagenetic and forming at the sea bed, its abundant occurrence suggests short-lived hiatuses and/or a generally slow depositional rate. Anomalously high values of glauconite in the detrital sand fraction occur in Unit VIB of the Barrow Group at 814.03 mbsf $(10 \%)$ and at 698.15 mbsf $(31.4 \%)$, and in the two samples from the Muderong Shale at $621.00 \mathrm{mbsf}(23.55 \%)$ and $610.02(34.3 \%)$, and these may represent hiatuses.

Figure 13 also illustrates the variation of quartz content $(50 \%-90 \%)$ in the detrital sand fraction, the overwhelming majority of the quartz being monocrystalline. Because the remaining material is less-resistant feldspar and lithic grains, higher quartz content reflects greater maturity of the sediment. There seem to be a number of cycles of increasing or decreasing maturity $30-100 \mathrm{~m}$ thick (arrows in Fig. 13). These cycles do not bear any clear relationship to the sequence stratigraphy of Haq et al. (this volume).

Polycrystalline quartz (Qp) is less stable than monocrystalline quartz $(\mathrm{Qm})$ in the sedimentary cycle (Dickinson, 1985), so higher Qm:Qp ratios indicate more mature sediment. The data in Table 3 indicate that increasing Qm:Qp ratios tend to parallel increasing quartz contents.

In summary, the Barrow Group at Site 763 appears to have been deposited in the upper prodelta as the delta built north, an interpretation which is supported by reflection seismic data (Boyd et al., this volume). The maturity cycles evident in the sand fraction (Fig. 13) probably represent changes in depositional rate, with less mature sediment being more rapidly 


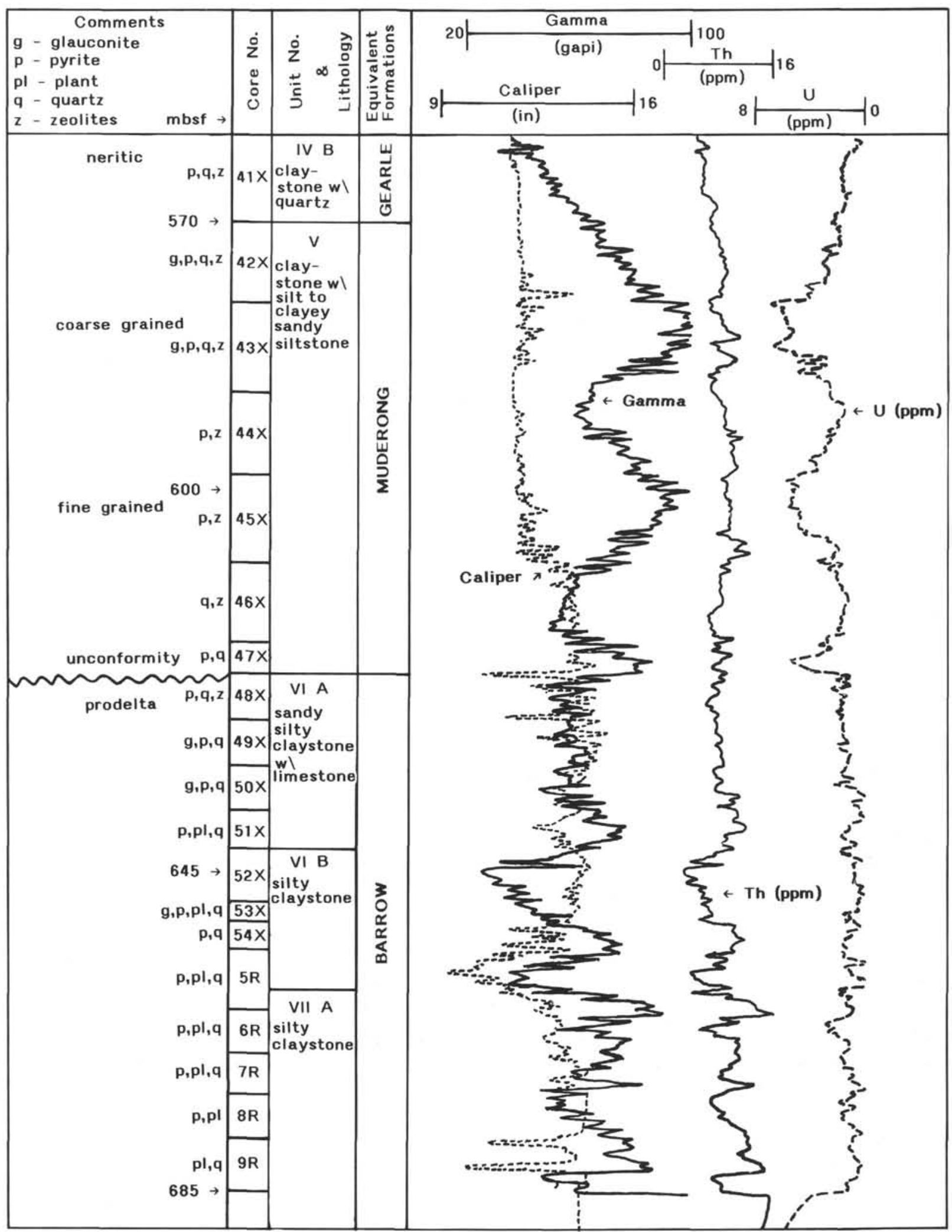

Figure 11. Detailed logs of part of Gearle-Muderong-Barrow sequence in Hole 763C, showing how wireline log character is related to lithostratigraphic units. 


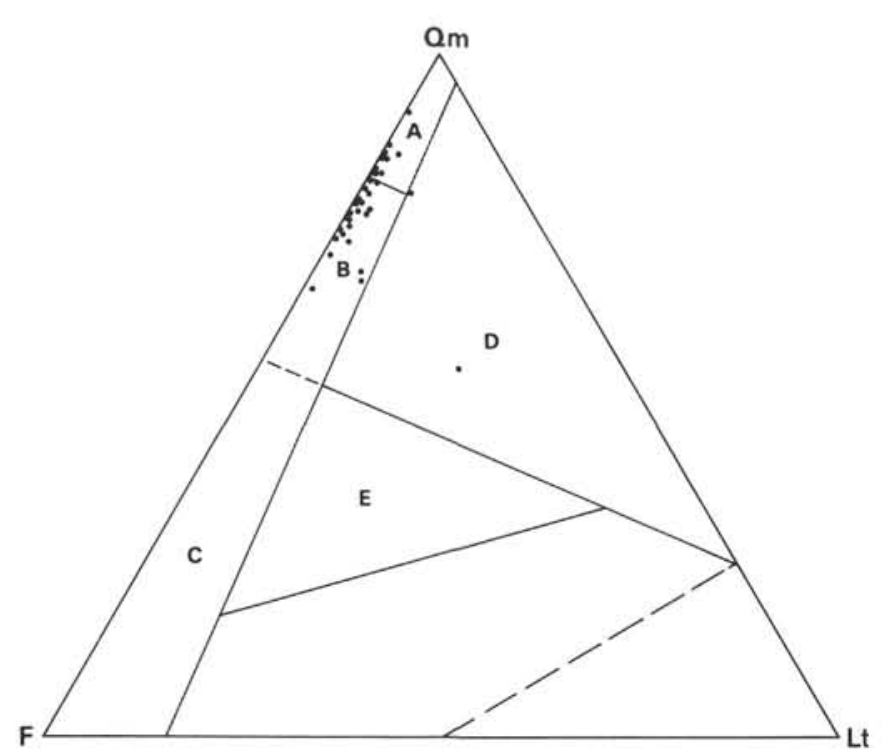

Figure 12. Triangular plot of composition of detrital sand grains $(>63$ $\mu \mathrm{m}$ ) in Lower Cretaceous sequence in Hole 763C. Qm = monocrystalline quartz grains, $\mathrm{F}=$ total feldspar grains, $\mathrm{Lt}=$ total lithic fragments; values from Table 3. Provenance fields from Dickinson (1985): $\mathrm{A}=$ cratonic interior, $\mathrm{B}=$ transitional continental, $\mathrm{C}=$ basement uplift, $\mathrm{D}=$ recycled orogen, and $\mathrm{E}=$ dissected arc.

deposited in the prodelta location represented by Site 763 . The changing depositional rates could represent changes in tectonism (Boyd et al., this volume), climate, or sea level.

Shallow marine ostracodes are common in the sediments (Damotte, this volume) and were apparently carried into deeper water by currents and mass transport. The benthic foraminifers found in the sequence generally suggest moderate water depths of 200-400 m (Jones and Wonders, this volume). The organic matter preserved in the sediments is largely of terrestrial plant origin (Rullkötter et al., this volume). The dominant lithology is mudstone with a median grain size of about $5 \mu \mathrm{m}$ (Fig. 7), but a peak of about $10 \mu \mathrm{m}$ (Fig. 9). There is an increase in coarse sand grains, glauconite pellets, and sandstone and limestone beds upward in the bulk of the sequence, Units VII and VIB, and a decrease in siderite. The increasingly reducing conditions and the increasing content of shallow-marine sand (rounded quartz and glauconite) possibly suggest a deepening environment with time, from prodelta to submarine fan deposition. However, the seismic stratigraphy indicates a continuous northward advance of the shoreline, suggesting that the increasing sand content is not necessarily related to increasing water depth (Boyd et al., this volume). The youngest sequence, Unit VIA, contains less sand and considerable siderite, which suggests shallowing again to a prodelta environment much like that of the lower part of Unit VII. In lithostratigraphic terms the oldest and younger sediments are of Flacourt Formation type and Unit VIB of Malouet Formation type.

\section{Site 762}

(848.5-940.0 mbsf, Unit VI, Cores $122-762$ C-81X to -91X) Near Site 762, the Barrow Group is considerably thinner than near Site 763 (Fig. 4). At the nearby Eendracht No. 1 well, it is $149 \mathrm{~m}$ thick; the upper $91.5 \mathrm{~m}$ is penetrated at Site 763. In Eendracht well the Barrow Group lies within five dinoflagellate zones, Kalyptea wisemaniae to Systematophora areolata (this uppermost zone is very thin). At Site 762 there are three zones identified, Dissimulidinium lobispinosum to Egmontodinium torynum, of middle Berriasian to earliest Valanginian age (Brenner, this volume, chapter 31). Overall then, there is little difference in the age of the sediments at Sites 762 and 763, although the distal deltaic sediments at Site 762 are much thinner.

At Site 762 , the Barrow Group consists of dark gray silty claystone and clayey siltstone, and thin, fine- to mediumgrained glauconitic sandstone. The content of organic carbon, at $0.6 \%-1.5 \%$, is much greater than it is in overlying units. Core recovery was only moderate, but the wireline logs suggest there is little variation within the sequence (Fig. 4). The mudstones (Fig. 4) commonly contain nannofossils, foraminifers (sporadically), dinoflagellates, spores and pollen, quartz, glauconite, pyrite, and plant debris. The lower part of the unit is massive to finely laminated, weakly to moderately bioturbated, glauconite-rich, and contains some belemnites and pyrite. It also commonly contains some molluscan shells, gray dolomitic limestone nodules, and one carbonate mudstone to wackestone bed with shell fragments. The upper part is massive and contains abundant belemnites and pyrite nodules.

Semiquantitative X-ray examination of the mudstones shows that quartz predominates over clay, feldspar is present, and calcite is virtually absent. Pyrite content is minor, and siderite appears in small quantities below $860 \mathrm{~m}$. Kaolinite is the dominant clay mineral, followed by smectite and then illite.

\section{General Discussion}

In summary, the Barrow Group is thinner and finer grained at Site 762 than at Site 763. Seismic data show that it lies well north of the delta front and beyond the prodelta in the distal basin (Boyd et al., this volume). The sedimentation rate has fallen from about $30 \mathrm{~cm} / \mathrm{k}$.y. at Site 763 to about $7 \mathrm{~cm} / \mathrm{k} . \mathrm{y}$. at Site 762. The upward decrease in molluscan shells, glauconite, siderite, bioturbation, and lamination suggests an increase in reducing conditions with time, and hence a possible deepening.

\section{Muderong Shale}

\section{Site 763}

(570.0-622.5 mbsf, Unit V, Cores 122-763B-42X to -47X)

At Site 763 , the Muderong Shale is $52.5 \mathrm{~m}$ thick and spans four dinoflagellate zones: Odontochitina operculata to $\mathrm{Mu}$ derongia testudinaria of middle Hauterivian to early Aptian age (Brenner, this volume, chapter 31), and about $8 \mathrm{~m} . \mathrm{y}$. according to Haq et al. (1987). It unconformably overlies the Barrow Group with a gap corresponding at least to the Phoberocysta burgeri and Senoniasphaerai tabulata zones, about $5 \mathrm{~m}$.y. The formation consists dominantly of dark gray to black claystone to clayey sandy siltstone (Pl. 2, Fig. 3). Minor dark gray limestone beds and a few nodules are also present. Core recovery is generally good and wireline logs (Fig. 11) confirm that there are broad fluctuations in clay and quartz content in the sequence.

The mudstones of the formation vary from massive to parallel-laminated (Pl. 2, Fig. 3) and are moderately bioturbated. The laminations sometimes contain stringers of shell debris. Burrows are normally horizontal and many are filled with early diagenetic pyrite. In general (Fig. 5) the mudstones contain nannofossils and dinoflagellates, occasional benthic foraminifers, radiolarians, spores, pollens, and echinoid fragments, common quartz, glauconite, and plant debris, and some pyrite. Coarse-fraction analysis shows that the quartz is very fine-grained and angular, and is often reddish-stained 

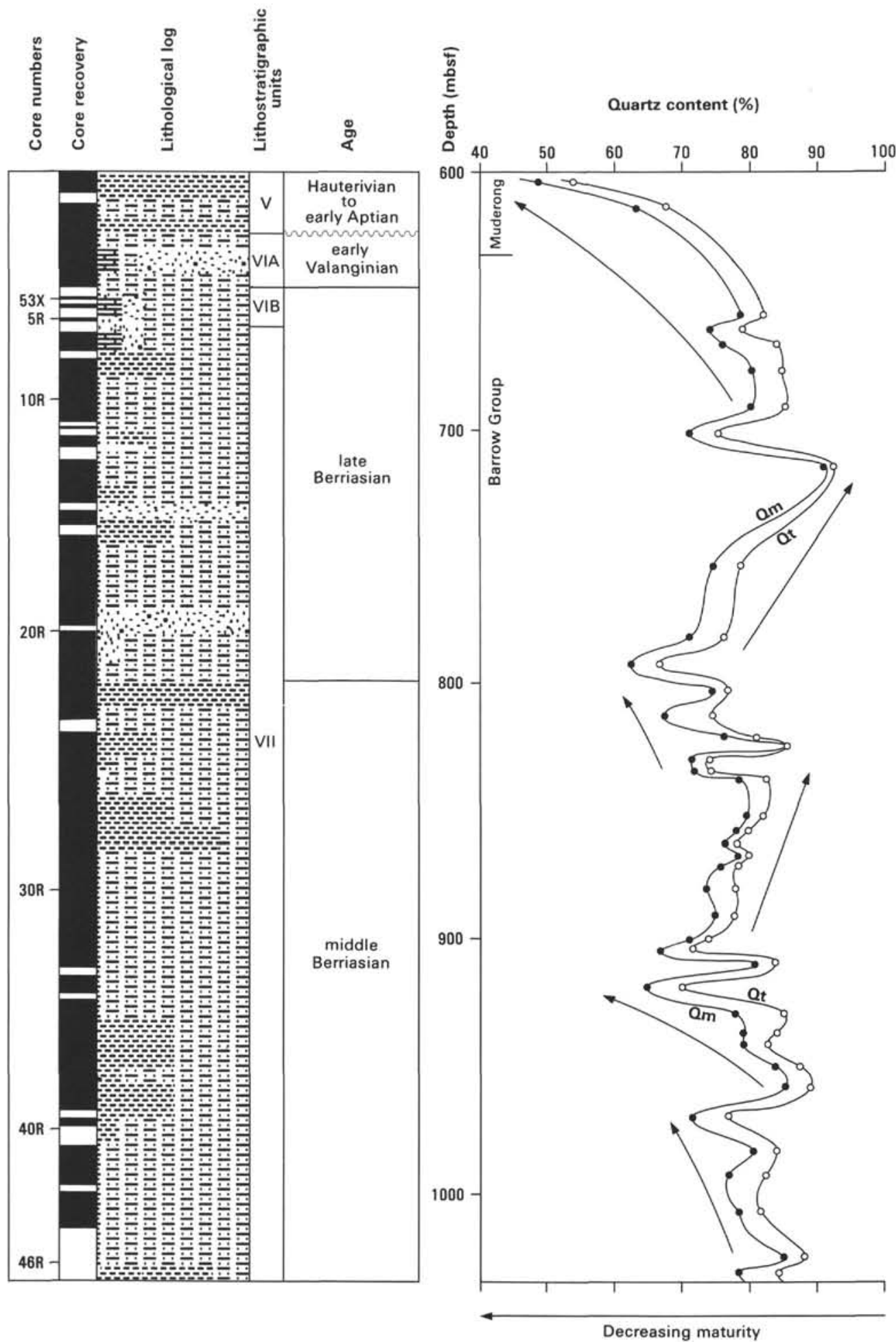

Glauconite content (\%)

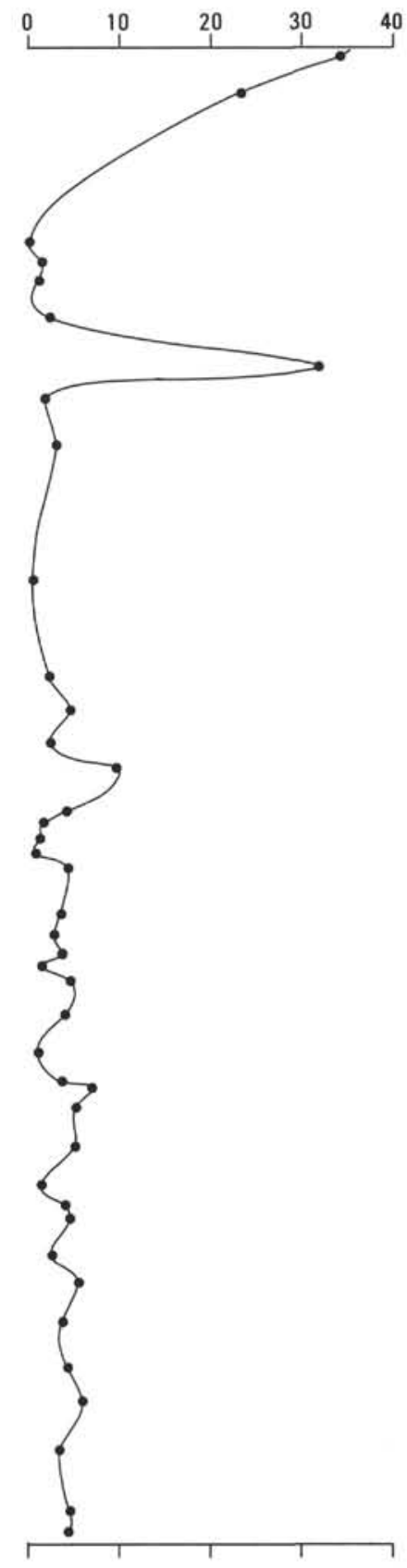

Figure 13. Plot of quartz and glauconite content (in sand fraction $>63 \mu \mathrm{m}$ ) against depth in Hole 763C. Qm $=$ monocrystalline quartz, Qt $=$ total quartz. Quartz content is percentage of quartz in detrital sand grains (excludes glauconite). Values derived from Table 3. Arrows show cyclic trends of increasing and decreasing maturity.

(probably derived from an arid terrain), and that the glauconite is very abundant, both as infillings of fossils (especially gastropods) and as fecal pellets. Other constituents include rare ammonites (but no belemnites), pyrite nodules, shell debris, and fish fragments. Organic carbon contents are mostly in the range $0.5 \%-1.0 \%$, and generally decrease up- ward. The early Aptian "Selli anoxic event" is represented in Core $122-763 \mathrm{~B}-44 \mathrm{X}$ to $-46 \mathrm{X}(0.5 \%-1.8 \%$ total organic carbon, or TOC).

Semiquantitative X-ray analysis of the mudstones shows that clay and quartz are roughly subequal and that there is minor feldspar. It confirms that pyrite is normally present and 
sometimes very abundant, and indicates that zeolite (clinoptilolite) is also often abundant; smectite is the dominant clay and illite a subordinate one.

One massive hemipelagic carbonate mudstone, $43 \mathrm{~cm}$ thick (Section 122-763B-43X-2, 30-73 cm), consists of recrystallized calcite containing ghosts of shelly material and peloids, possibly including foraminifers and fecal pellets. Glauconite and pyrite are present in some of the peloids. Other limestones are recrystallized peloidal mudstones with ghosts of fossils, apparently gastropods and foraminifers. The limestone nodules and concretions are up to $5 \mathrm{~cm}$ in diameter.

\section{Site 762}

(838.5-848.5 mbsf, Unit V, Cores $122-762 \mathrm{C}-79 \mathrm{X}$ to $-80 \mathrm{X}$ )

Here the Muderong Shale is only $10 \mathrm{~m}$ thick and includes two spore zones: Muderongia australis and Muderongia testudinaria, of middle Hauterivian to latest Barremian age (Brenner, this volume, chapter 31) and covering about $5 \mathrm{~m} . \mathrm{y}$. Hence, the upper part of the unit (early Aptian) of Site 763 is missing. The formation unconformably overlies the Barrow Group with an apparent gap of three dinoflagellate zones, Phoberocysta burgeri to Systematophora areolata, amounting to about $8 \mathrm{~m} . \mathrm{y}$. , more than at Site 763 .

The formation consists of parallel-laminated, dark gray calcareous claystone, with moderate to strong bioturbation and a little cross-lamination. The early Aptian "Selli ancxic event" is represented in Section 122-762C-79X-2, 109-111 $\mathrm{cm}$, by a total organic carbon value of $0.8 \%$. Core recovery is very good. The formation (Fig. 4) contains nannofossils, a few foraminifers, and dinoflagellates, spores, pollen, glauconite, and pyrite. Semiquantitative X-ray analysis shows that the claystones contain roughly equal portions of clay and quartz, abundant zeolite and some pyrite, and that smectite predominates over illite.

\section{General Discussion}

The unconformable contact with the underlying Barrow Group generates the regional "D"' seismic reflector of Exon and Willcox (1980). The sequence at Site 762 is so condensed, with a sedimentation rate of only a couple of meters per million years, that it is much less informative than the sequence at Site 763 . The Site 762 sequence is truncated at the top, probably by erosion, and the sediments were probably laid down in similar conditions to those at Site 763 , so we concentrate on the latter in this discussion.

At Site 763 the sedimentation rate of about $10 \mathrm{~m} / \mathrm{m} . y$. is much lower than that of the Barrow Group, in line with the widespread occurrence of zeolites and glauconite infillings. The generally laminated and muddy nature of the sediments and the presence of nannofossils suggest outer shelf deposition. The variations in grain size and bioclastic and terrigenous debris indicate higher energy periods, perhaps related to the numerous transgressive/regressive global eustatic cycles (Fig. 10), or to storms. Conditions in the sediment were moderately reducing because of the plant debris, as attested by the high pyrite, but not enough to stop bioturbation.

\section{Gearle Siltstone}

The sequence we have designated as Gearle Siltstone is in reality of a transitional type, with some characteristics of the Haycock Marl and the Windalia Radiolarite. At Site 762 it is very thin and clearly distinguished from the Haycock Marl but not from the unconformably overlain Muderong Shale on the resistivity $\log$ (Fig. 4); on the gamma-ray log it is intermediate in character between the underlying and overlying units. At Site 763 , where the sequence is better developed, the lower part of the Gearle Siltstone is indistinguishable from the unconformably overlain Muderong Shale (or the Haycock Marl) on the resistivity log but is distinguishable from both these units by low values on the gamma-ray log (Fig. 5); the upper part of the formation is a characteristic limestone.

\section{Site 763}

(532.0-570 mbsf, Unit IVB, Cores 122-763B-38X to -41X) Here the Gearle Siltstone is $38 \mathrm{~m}$ thick and it unconformably overlies the Muderong Shale. It contains the NC7 and NC8-9 nannofossil zones of Roth (1978); the NC7 zone varies from late Aptian to early Albian and the NC8-9 zone from late early Albian to early late Albian (Haq, von Rad, O'Connell, et al., 1990). The foraminifers in Cores 122-763B-38X and -39X are Aptian-Albian in age, and there is no foraminiferal age data from the younger cores. Palynological evidence indicates that the upper part of the formation is Albian but, on very weak evidence, suggests that the lower part may possibly be late Aptian (Brenner, this volume, chapter 31). If the regional situation applies here (see "Regional Cretaceous Geology" section, this chapter) the lower boundary of the Gearle Siltstone is likely to be early Albian in age, so that the entire formation is probably early Albian. If this is the case, the late Aptian is missing at this site, a time break of about 2 m.y.; we assume that this is the case and that the formation is indeed early Albian in age.

The formation consists of dark green-gray claystone concentrated low in the unit, and silty claystone concentrated higher in the unit. Lighter-colored recrystallized limestones occur toward the top. Core recovery is generally good, although wireline logs indicate some limestones were not recovered. The formation is heavily bioturbated and generally contains (Fig. 5) nannofossils, quartz, and glauconite; radiolarians are present in the lower claystone part, and foraminifers and dinoflagellates in the upper limestone-mudstone part. Semiquantitative X-ray analysis clearly differentiates the lower and upper parts: the lower part contains subequal proportions of clay, quartz, and calcite, whereas calcite is very dominant in the upper part. Smectite dominates in the clay minerals, with illite and kaolinite sporadically present. There are traces of zeolite and pyrite in some beds. The mudstones are generally laminated and not strongly bioturbated. They contain an average of $1 \%$ TOC (Haq, von Rad, O'Connell, et al., 1990). Overall the formation increases upward in biogenic components, largely nannofossils, and decreases in clay, quartz, and glauconite. Rare detrital minerals, such as zircon and kyanite, suggest a metamorphic source area.

The carbonates are recrystallized and sideritic or dolomitic, and some may result from the alteration of pre-existing marly sediments. There are green, gray and white, decimeterthick color cycles throughout the formation. These are strongly correlated with variable proportions of clay and carbonate, and are probably climatically controlled by Milankovitch cycles.

\section{Site 762}

(830.0-838.5 mbsf, lower Unit IVE, Core 122-762C-78X)

This thin sequence is picked above the unconformity with the Muderong Shale, and below a major positive resistivity kick (Fig. 4) at the base of the overlying Haycock Marl. The Gearle Siltstone equivalent is a white nannofossil chalk with clay, with early Albian nannofossils. Early Aptian foraminifers from Sample 122-762C-78X-CC are presumably from beneath the unconformity because the lower part of the sequence was not recovered. The chalk is clayey and contains abundant foraminifers in three thin beds. It also contains many thin, diffuse anastomosing green clayey layers, probably 
the residual material from dissolution and compaction. The clays contain zeolites and illite. Other constituents (Fig. 4) are radiolarians, glauconite, pyrite, and plant debris.

\section{General Summary}

These sediments are outer shelf mudstones, marls, and limestones (Site 763) and outer shelf chalks (Site 762), which represent the transition from dominantly terrigenous to dominantly pelagic carbonate sedimentation. They are not precisely dated but are probably early Albian in age. Depositional rates are clearly low, like those in the overlying and underlying formations, and hiatuses are present. The pelagic influence, with both clay and calcareous nannoplankton being deposited, meant that climatic changes could readily influence these rocks, giving color cycles tens of centimeters thick at Site 763. These are the oldest color cycles in sediments in this area.

\section{Haycock Marl}

The Haycock Marl is a relatively homogeneous sequence which conformably overlies the Gearle Siltstone, and is overlain by the Toolonga Calcilutite. It is well-developed at Site 763 but compressed at Site 762 .

\section{Site 763}

(371.0-532.0 mbsf, Units IIIC (lower) and IVA, Cores 122-763B-21X to $-37 \mathrm{X}$ )

The base of this 161-m-thick unit is taken above the limestone at the top of the Gearle Siltstone, and the top as below the limestones of the Toolonga Calcilutite; both are clearly visible in the resistivity log. This means that the black claystones marking the anoxic event at the CenomanianTuronian boundary are within the upper Haycock Marl, as is the case in the type section (see "Regional Cretaceous Geology" chapter, this section). At Site 763 there is a hiatus at this level, between the Turonian and the Cenomanian. The Haycock Marl (Fig. 5) approximates log units " $G$ " and "F"' of Boyd and Bent (this volume). Nannofossil determinations indicate that the Haycock Marl is of late Albian to Turonian age, extending from near the base of the Eiffellithus turriseiffelii event to above the base of the Quadrum gartneri event. Foraminiferal determinations suggest that the formation is of Albian to late Turonian or Coniacian age. We conclude that the probable age is late Albian to early late Turonian, covering a span of about $10 \mathrm{~m} . \mathrm{y}$.

The Haycock Marl at Site 763 consists largely of heavily bioturbated, green to gray nannofossil claystone (Unit IVA) and green clayey chalk (Unit IIIC). These marly sequences are color-banded (bands 10 to $35 \mathrm{~cm}$ thick) from light to dark, with more calcareous beds being lighter in color.

The lower and middle Albian part of the formation (Fig. 5) contains nannofossils, foraminifers, glauconite, and pyrite; bivalve shell debris includes Inoceramus prisms and there are rare belemnites. Semiquantitative X-ray analysis shows subequal calcite and clay, and abundant quartz and zeolites. The dominant clay mineral varies throughout the section. Pyrite nodules and dolomite rhombs occur at some levels (PI. 3, Fig. 1).

The upper (upper Albian to Turonian) part of the formation (Fig. 5) contains nannofossils, foraminifers, and glauconite, and intermittent dinoflagellates and pyrite. X-ray analysis shows calcite very dominant, clay and zeolites abundant, and moderate quantities of quartz. Smectite is generally the dominant clay, giving way to kaolinite above the CenomanianTuronian boundary.

Core $122-763 \mathrm{C}-2 \mathrm{R}$, from the Cenomanian-Turonian boundary at 385.7 mbsf, shows a sharp contact between lightcolored Cenomanian clayey nannofossil chalk below, and dark greenish gray to black sapropelitic claystone (9\%-15\% TOC) with zeolites above. The claystone, which represents the Cenomanian-Turonian boundary anoxic event, gives way upward, over about $75 \mathrm{~cm}$, to normal Turonian clayey chalk.

\section{Site 762}

(799.0-883.0 mbsf, Unit IVE (upper) and Unit IVD (lower), Cores $122-762 \mathrm{~B}-73 \mathrm{X}$ to $-77 \mathrm{X}$ )

The 84-m-thick Haycock Marl at Site 762 consists of green-gray nannofossil chalk with foraminifers and nannofossil chalk with clay (Pl. 3, Fig. 2), and hence is more pelagic and calcareous than the equivalent sequence at Site 763 . This is reflected in the higher resistivity shown in the wireline logs (Fig. 4). Nannofossil determinations place the base of the formation at the base of the Eiffelithus turreiffelii event and its top at the base of the Reinhardtites levis event, giving an age of late Albian to early Coniacian. Foraminifers give an age of early to middle Albian at the base, to late Turonian to Coniacian at the top. We conclude that the age is fairly similar to that of the sequence at Site 763 , middle Albian to early Coniacian, and that the formation spans a little over 10 m.y. The formation (Fig. 4) contains abundant nannofossils and common foraminifers and echinoids. It is strongly bioturbated in the upper part. Molluscs, including Inoceramus prisms, rare belemnites, ostracodes, and glauconite and pyrite, are present in the lower part. Semiquantitative X-ray analysis shows that calcite is greatly dominant over clay and quartz, zeolites and pyrite are present in trace amounts, and illite is generally the dominant clay mineral.

The lowermost (Albian) part of the formation is dominantly green, and the remainder of the formation is dominantly brown. The green part contains alternating light green-gray $\left(\mathrm{CaCO}_{3} 70 \%-90 \%\right)$ and green-gray beds $\left(\mathrm{CaCO}_{3} 60 \%\right)$ in couplets of highly variable thickness $(15-110 \mathrm{~cm})$. The brown part contains alternating brown $\left(\mathrm{CaCO}_{3} 50 \%-75 \%\right)$ and light brown to white $\left(\mathrm{CaCO}_{3}>90 \%\right)$ beds, in couplets 7 to $85 \mathrm{~cm}$ thick.

There is much more claystone in the sequence above the Cenomanian-Turonian boundary (Core 122-762C-75X-1, 137 $\mathrm{cm} ; 810.85$ mbsf) at Site 762 (Pl. 3, Fig. 3) than at Site 763. Light green-gray to light olive brown, late Cenomanian clayey nannofossil chalk is abruptly overlain by dark brown shale, which grades upward to light olive brown shale over $80 \mathrm{~cm}$. There is no paleontological evidence of a time break. Above the shale is another $90 \mathrm{~cm}$ of interbedded early Turonian nannofossil claystone and clayey nannofossil chalk, containing a $2-\mathrm{cm}$ section of very dark gray claystone. Above the shale-claystone sequence are normal white to pale gray nannofossil chalks with foraminifers or clay. The shale-claystone sequence, $170 \mathrm{~cm}$ thick, has a very characteristic gamma-ray kick (Fig. 4). Heath and Apthorpe (1984) recognized that it represents the worldwide anoxic event identified by Scholle and Arthur (1980) and other workers. They also noted that in the Carnarvon Basin this widespread unit generally lacks calcareous foraminifers but contains pyritized radiolarians and arenaceous foraminifers.

\section{General Summary}

The Haycock Marl shows the continuing replacement of hemipelagic mud by pelagic carbonate with time. Sedimentation rates were of the order of $10-15 \mathrm{~m} / \mathrm{m}$.y. At Site 763 , the lower part of the formation consists of nannofossil claystone and the upper part of chalk with clay. This presumably reflects the continuing reduction of relief in the hinterland, with a corresponding decline in derived clay. At Site 762, the entire formation consists of chalk with clay, indicating that there was less input of land-derived clay at Site 762 than at Site 763. 
The light and dark cycles in the formation depend on clay content and probably on climatic changes driven by Milankovitch cycles. The broad dating of the sequence suggests that the most likely controlling mechanisms are the Milankovitch 21,000 -yr precession cycle and the 41,000 -yr obliquity cycle. The change at Site 762 , from dominantly green sediments in the Albian, to dominantly red sediments in the remainder of the formation, must reflect a change in oxidation state. The change from reduced to oxidized sediments probably reflects a decline in enclosed organic matter, and coincides with the disappearance of plant debris and pyrite.

The worldwide anoxic event at the Cenomanian-Turonian boundary is especially well developed as black claystone at Site 762. The claystone generally lacks calcareous foraminifers but contains arenaceous foraminifers and radiolarians which are commonly pyritized (zeolitized in Core 122-763C$2 \mathrm{R})$. The formation of the claystone is clearly related to deposition in oxygen-depleted acid waters, leading to the solution of calcareous material and the formation of pyrite. This may be caused by upwelling associated with the early Turonian sea level rise (J. Thurow, pers. comm., 1990, to U. von Rad).

\section{Toolonga Calcilutite}

The Toolonga Calcilutite is a relatively dense sequence which is distinguished by a strong positive anomaly in the resistivity logs (Figs. 4 and 5). The contact with the underlying, less dense Haycock Marl generates the regional "C" seismic reflector of Exon and Willcox (1980).

\section{Site 763}

(346.3-371.0 mbsf, Unit IIIC (upper)-Unit IIIB (lower), Cores $122-763 \mathrm{~B}-18 \mathrm{X}$ to $-20 \mathrm{X}$ )

Here the Toolonga Calcilutite is $24.7 \mathrm{~m}$ thick and varies from the top of the Eprolithus floralis nannofossil event to above the base of the Quadrum gartneri event, spanning an age of early late Turonian to Santonian (about 2 m.y.). The foraminifers give an age of Coniacian to late Turonian at the base and Santonian at the top. We take the age as latest Turonian to earliest Santonian. The formation approximates log unit "E" of Boyd and Bent (this volume).

The formation consists of subtly color-banded nannofossil chalk and clayey nannofossil chalk with some foraminifer-bearing beds. The colors vary from green-gray to graygreen, with light layers containing more carbonate and dark layers less (total range $90 \%-50 \% \mathrm{CaCO}_{3}$ ). The sequence (Fig. 5) is dominantly nannofossils with abundant foraminifers and is bioturbated in the upper part. Semiquantitative $\mathrm{X}$-ray analysis shows the dominance of calcite, the presence of considerable clay, and very small amounts of quartz, zeolite, and pyrite; the clay minerals are dominated by smectite or illite. Bioturbation has generally formed ellipsoidal chalk-filled burrows, but a few pyritized circular burrows are also present.

\section{Site 762}

(780.0-799.0 mbsf, Unit IVD (upper), Cores 122-762C-69X to $-72 \mathrm{X}$

Here the Toolonga Calcilutite is slightly thinner $(19 \mathrm{~m})$ than at Site 763 and ranges from above the top of the Eprolithus floralis nannofossil event to above the base of the Reinhardtites levis event (i.e., from middle Coniacian to middle early Santonian-about $2 \mathrm{~m} . y$.). Foraminifers indicate an age varying from Coniacian to late Turonian in the lower part, to Santonian in the upper part. We take the age as being middle Coniacian to early Santonian, the base of the formation being somewhat older than at Site 763 .
The formation consists of light green-gray nannofossil chalk with foraminifers, and brown clayey nannofossil chalk. There are cyclic color changes with color bands generally 5-50 cm thick; calcium carbonate contents are generally $80 \%-90 \%$, the highest values being in the lightest beds. The unit (Fig. 4) is dominated by nannofossils, contains abundant foraminifers, some ostracodes, is moderately bioturbated, and commonly contains considerable kaolinite, and minor illite and quartz.

\section{General Discussion}

The Toolonga Calcilutite is readily distinguished from the underlying and overlying units on wireline logs. Its base is marked by a rapid decline in clay content, especially in the more distal Site 762 , which is the regional pattern on the western Australian margin. However, the age of its base, as old as middle Coniacian, is older than that in the more proximal areas on the Northwest Shelf-Santonian (see "Regional Cretaceous Geology" section, this chapter).

The formation was deposited on the outer shelf as a pelagic sediment and shows similar color cycles to those in the underlying and overlying units. The color cycles are presumably climatically controlled and may have been forced by Milankovitch precession (21 Ka) and obliquity $(41 \mathrm{Ka})$ cycles. Sedimentation rates are low, about $10 \mathrm{~m} / \mathrm{m} . \mathrm{y}$.

\section{Upper Cretaceous Carbonates}

The Upper Cretaceous sequence conformably overlying the Toolonga Calcilutite consists largely of upper bathyal chalks. It is different from the carbonate units known from the Northwest Shelf, so we are not applying established stratigraphic names to it. The sequence is relatively thick and complete in Site 762 (Fig. 4), but compressed and missing the Maestrichtian at Site 763 (Fig. 5). At both sites it is characterized by low gamma-ray log values and low to moderate resistivity values. Core recovery is very good.

\section{Site 762} $-68 \mathrm{X})$

(554.8-780.0 mbsf, Units IVA-C, Cores $122-762 \mathrm{~B}-43 \mathrm{X}$ to

At this site the sequence is $325.2 \mathrm{~m}$ thick and nannofossil determinations suggest that it is continuous and varies from late early Santonian to latest Maestrichtian in age. Foraminifers suggest an age of Santonian to late Maestrichtian. We assume an age of earliest Santonian to latest Maestrichtian, a period of about $21.5 \mathrm{~m}$.y. This indicates an average sedimentation rate of $15 \mathrm{~m} / \mathrm{m} . \mathrm{y}$. Lower Paleocene chalks sit on the Upper Cretaceous sequence, and there is almost no time break at the Cretaceous/Tertiary boundary.

The sequence consists of white to light green-gray nannofossil chalk, and green-gray or reddish brown clayey nannofossil chalk. Calcium carbonate values generally lie between $80 \%$ and $95 \%$, and are never less than $55 \%$, so the shipboard identification of abundant nannofossil claystone cannot be substantiated. The sequence consists of three lithostratigraphic units, which are described below.

The oldest unit, Unit IVC, lies between 697.0 and 780.0 mbsf and consists of white to very light green-gray nannofossil chalk with foraminifers and clayey nannofossil chalk. Its age is earliest Santonian to early Campanian, and it is characterized by particularly low values on gamma-ray and resistivity logs (Fig. 4). It contains echinoid fragments, Inoceramus prisms, ostracodes (Damotte, this volume), and sporadic radiolarians and pyrite, and is moderately bioturbated. Semiquantitative X-ray analyses show that its clay content varies from almost none to appreciable (illite or kaolinite), and that it contains occasional traces of zeolites and pyrite. It generally 
contains $90 \%-95 \%$ calcium carbonate (Fig. 6), with the darker, more clayey beds being less carbonate-rich. Some lighter beds contain nodules of pyrite or chert.

The middle unit, Unit IVB, lies between 603.5 and 697.0 mbsf and consists of light green-gray nannofossil chalk and reddish brown clayey nannofossil chalk. Its age is early Campanian to early Maestrichtian and it is characterized by low (but increasing upward) values on the resistivity $\log$ and low (but higher than in the surrounding units) values on the gamma-ray log (Fig. 4). It contains foraminifers, Inoceramus prisms, and ostracodes, and echinoid fragments in its lower part, and it is strongly bioturbated with many identifiable trace fossils. Semiquantitative X-ray analysis shows considerable clay (various mixtures of illite, kaolinite, and smectite) and traces of zeolites. Its calcium carbonate content varies from $60 \%$ to $90 \%$ (Fig. 6), with the darker beds containing more terrigenous material and less carbonate. Anastomosing clayey seams that are parallel to the bedding may represent pressure solution, with calcium carbonate being dissolved.

The youngest unit, Unit IVA, lies between 554.8 and 603.5 mbsf and consists of white to light green-gray clayey nannofossil chalk. Its age is Maestrichtian, and it is characterized by low values on the gamma-ray log and moderate values on the resistivity $\log$ (Fig. 4). It contains foraminifers and is moderately to strongly bioturbated with many identifiable trace fossils. It has some pyrite crystals near its base. Semiquantitative X-ray analysis shows that its lower part contains substantial quantities of clay (smectite, illite, and kaolinite) and quartz, which decline to almost nothing above $570 \mathrm{~m}$; traces of zeolite are present in places. Calcium carbonate values are generally $75 \%-95 \%$ (Fig. 6), but occasional dark beds contain as little as $55 \% \mathrm{CaCO}_{3}$.

\section{Site 763}

(247.0-346.3 mbsf, Units IIIA and IIIB, Cores 122$763 \mathrm{~B}-8 \mathrm{X}$ to $-17 \mathrm{X}$ )

At this site the sequence is $99.3 \mathrm{~m}$ thick (Fig. 5), and nannofossil determinations suggest that it is continuous and varies in age from late Santonian to late Campanian. It corresponds to log units " $C$ " and "D" of Boyd and Bent (this volume). Foraminifers indicate an age of Santonian to late Campanian. We assume an age of late early Santonian to late Campanian, a period of about $12 \mathrm{~m}$.y. Middle Eocene chalks rest unconformably on the Late Cretaceous sequence, leaving a gap of $35 \mathrm{~m} . \mathrm{y}$.

The sequence consists of varicolored foraminifer nannofossil chalk and nannofossil chalk with foraminifers. Ostracodes are commonly present (Damotte, this volume). Calcium carbonate values generally lie between $75 \%$ and $90 \%$. The sequence consists of two lithostratigraphic units which are described below.

The older unit, essentially Unit IIIB, is here taken as lying between 251.5 and 346.3 mbsf (its base being roughly $7 \mathrm{~m}$ above that of the lithostratigraphic unit defined aboard ship). It consists of light green-gray, pale green, and white foraminifer nannofossil chalk and nannofossil chalk with foraminifers. Its age is early Santonian to late Campanian. It contains some pyrite and is strongly bioturbated, with many identifiable trace fossils. Semiquantitative X-ray analysis shows that it contains moderate quantities of clay $(<20 \%$ : kaolinite and illite) and quartz $(<10 \%)$ that tend to increase upward, and traces of zeolites.

The younger unit, Unit IIIA, is between 247.0 and 251.5 mbsf. It consists of $4.5 \mathrm{~m}$ of coarsening-upward, pale-green foraminifer nannofossil chalk with glauconite and quartz, beneath a major unconformity. Radiolarians, echinoid fragments, and Inoceramus prisms are present. Horizontal and vertical burrows and mottles are common, and some burrows contain silty to sandy infillings of glauconite, quartz, and pyrite. Pyrite and glauconite also occur as disseminated grains and infillings of foraminiferal tests, and there are traces of zeolites. The calcium carbonate content decreases upward from $80 \%$ to $67 \%$, as clay and quartz increase.

\section{General Discussion}

The two ODP sites contain outer shelf and upper bathyal pelagic chalks and marly chalks, which were laid down with sedimentation rates of about $15 \mathrm{~m} / \mathrm{m}$.y. (Site 762) and $8 \mathrm{~m} / \mathrm{m} . \mathrm{y}$. (Site 763). It appears that Site 763 was considerably shallower than Site 762 at some stage and was subject to submarine erosion which removed Maestrichtian, Paleocene, and early Eocene sediments or prevented their deposition. This erosion may have taken place by Eocene waves or shallow-water currents, following folding related to collision of Australia with the Sunda arc. The uppermost Campanian sediments contain concentrations of quartz and glauconite which suggest a period of winnowing as deposition ceased.

The entire Upper Cretaceous chalky sequence contains color cycles that are related to variations in the clay/carbonate ratio. These variations have been studied in early Campanian to Maestrichtian sediments by Huang et al. (this volume) who identified two sets of cycles: $4-41 \mathrm{~cm}$ and $71-84 \mathrm{~cm}$ thick. Assuming a sedimentation rate of $1.9 \mathrm{~cm} / \mathrm{k} . \mathrm{y}$., these cycles correspond to periods of $21,000 \mathrm{yr}$ and $41,000 \mathrm{yr}$, and fit very well with the Milankovitch orbital precession and obliquity cycles.

Huang et al. (this volume) go on to propose that, as there were no continental glaciations, the cycles must be controlled by insolation. They elegantly argue that wet, equable, and warm periods lead to more erosion, run-off, and deposition of dark clayey beds offshore, and that dry, cold periods lead to less erosion, less run-off, and deposition of light-colored, highly calcareous beds. Oxidation states in the sediment probably decide whether cycles are green, gray, or red.

\section{DISCUSSION}

The Cretaceous sequences drilled at Sites 762 and 763 have helped considerably in detailing the geological history of the Exmouth Plateau, especially in the period of rapid change from the Neocomian to the Albian (Fig. 14). In the Jurassic there was considerable faulting in the region and thick shallow-marine sequences were laid down in northeasterly trending, fault-bounded depocenters like the Kangaroo Syncline (easternmost Exmouth Plateau) and the downwarp of the Exmouth, Barrow, and Dampier Sub-basins beneath the Northwest Shelf (Powell, 1976; Exon and Willcox, 1980; Boote and Kirk, 1989). However, on the central and western Exmouth Plateau the Jurassic sequence is condensed and intermittent in occurrence, and when Cretaceous deposition began it was onto (or virtually onto) Upper Triassic sediments, with substantial fault blocks forming an irregular surface with highs and lows trending northeast (Exon and Willcox, 1980; Barber, 1988).

In the Berriasian there was a sudden flood of deltaic sediments of the Barrow Group across the area from the south (Fig. 14A), reaching a peak sedimentation rate of around 300 $\mathrm{m} / \mathrm{m} . \mathrm{y}$., and this terminated just as suddenly in the early Valanginian on the plateau. Veevers and Powell (1979) and Exon and Buffler (this volume) provide indirect evidence that a large part of the Barrow Group sediment was provided by a major ridge, probably on the order of two kilometers high, which formed by thermal doming above the future Cape Range Fracture Zone (CRFZ), the zone of breakup, by shearing southwest of the Exmouth Plateau. This provided 

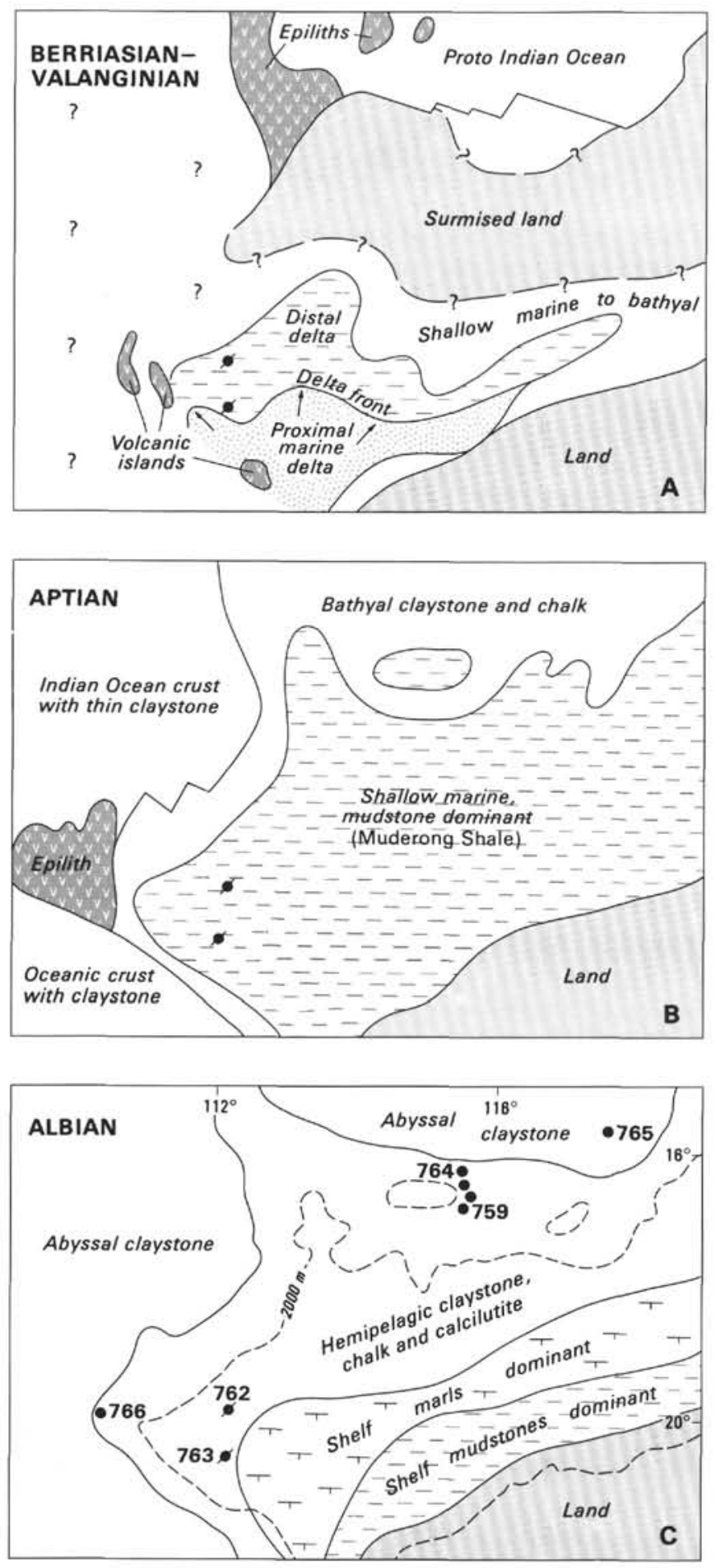

Figure 14. Paleogeographic sketch maps of (A) Berriasian-Valanginian, (B) Aptian, and (C) Albian. After Exon et al. (this volume). The data used are from commercial wells, ODP sites (shown in C), dredging, and interpretation of seismic data. The present shoreline and $2000-\mathrm{m}$ isobath are shown with a dotted line in (C). The three maps illustrate the history of the area in the periods immediately before and after the breakup of Australia and Greater India in the Valanginian. The later Cretaceous history was one of steady subsidence, a decrease of detrital input, and an increase in biogenic pelagic carbonate input. reworked sediments for the prograding delta and collapsed immediately after breakup, thus cutting off the sediment supply. An eastern sediment source in the Pilbara Block may also have been important, at least in the Barrow Sub-basin and eastern Exmouth Plateau (Boote and Kirk, 1989). Boyd et al. (this volume) make a strong case for another major sediment source in the uplifted area where the CRFZ met the northsouth spreading center which led to the formation of the Cuvier Abyssal Plain.

Palynological evidence of extensive reworking of preCretaceous sediments into the Barrow Group comes from Sites 762 and 763, and from Vinck and Eendracht wells (R. Helby, pers. comm., 1990; W. Brenner, pers. comm., 1990). In the ODP holes (upper Barrow Group) there is continuous reworking of Permian spores and pollen, and sporadic reworking of Triassic forms. Upper Jurassic microplankton of Oxfordian, Kimmeridgian, and Tithonian ages are also reworked. In Vinck and Eendracht wells, which penetrated the entire Barrow Group, reworking of Triassic spores and pollen occurs sporadically. Permian reworking is very common, especially low in the group, and Carboniferous reworking is generally rare, but common in the lowermost sequence in Eendracht well. This shows that much of the material eroded and redeposited was sedimentary rock, some as old as Carboniferous, providing support for the view that there was marked uplift and erosion associated with the rifting immediately preceding seafloor spreading.

Figure 14A illustrates the situation during the early Neocomian. The Barrow delta was fed from the uplift along the southwestern margin of the future Exmouth Plateau and from the land mass in the southeast. Although Greater India lay to the southwest, the ridge between it and the plateau prevented it from providing sediment to the delta. Three volcanic highs in the southwest (Fig. 14A), probably of latest Triassic to earliest Jurassic age (Exon and Buffler, this volume), formed islands in the earliest Cretaceous ocean and were planated by wave action in the Berriasian, shedding sediment for local sand bodies in the process. The proximal marine delta further east, consisting largely of sandstone and siltstone, is up to $1500 \mathrm{~m}$ thick and built northward with time. The maximum extent of the delta front (Boyd et al., this volume; Erskine and Vail, 1988) lies just south of Site 763, and the site contains 414 $\mathrm{m}$ of predominantly prodelta mudstones with some turbidite sandstones (Fig. 5). In the adjacent Vinck No. 1 well the whole deltaic sequence, $677 \mathrm{~m}$ thick, was drilled. Site 762 is toward the limit of the distal delta and contains $91 \mathrm{~m}$ of prodelta and basin-floor mudstones. In the adjacent Eendracht No. 1 well the whole deltaic sequence is $149 \mathrm{~m}$ thick. Water depths during deposition of the Barrow Group were 200-400 $\mathrm{m}$ in the two ODP sites. Well north of the delta, which had been loading and depressing the Triassic surface, the water was apparently shallow, and thin bathyal to shallow-marine sequences were laid down. Farther north on the plateau virtually no sediments are preserved; that area may have been a land mass (Fig. 14A). Certainly, at the ODP sites on the Wombat Plateau, there is evidence of an early Neocomian transgression (von Rad et al., this volume), presumably related to subsidence after Tithonian breakup in the north (Ludden, Gradstein, et al., 1990). A broad Triassic-Jurassic volcanic belt, extending southwest from the surmised land to the westernmost volcanic islands (Exon and Buffler, this volume), was probably a shallow marine arch, which provided some detritus (including plagioclase) to the Barrow delta.

After late Valanginian breakup in the south and west (Fullerton et al., 1989) there was steady subsidence in the Carnarvon Basin. A major late Neocomian and Aptian transgression deposited the diachronous Mardie and Birdrong 
sandstones in the east before they were covered by the Muderong Shale (Wiseman, 1979). However, there is no sand body between the Barrow Group and the Muderong Shale in the central Exmouth Plateau, with the transgression being marked by Hauterivian and Barremian Muderong (largely outer shelf) mudstones at both ODP sites. Figure 14B shows how most of the region was covered by the Muderong Shale in the Aptian. Muderong deposition continued into the early Aptian at Site 763 (Fig. 5), but there is no early Aptian mudstone at Site 762 (Fig. 4), perhaps because of later erosion. At both sites there are clear hiatuses beneath the Muderong Shale. This formation contains reworked Permian and Triassic spores and pollen (R. Helby, pers. comm., 1990; W. Brenner, pers. comm., 1990), probably still derived from uplifted areas to the southeast, or perhaps reworked from the Barrow Group. Beyond the extent of Muderong Shale deposition, bathyal claystone and chalk were laid down on the slopes of the newly-forming Exmouth Plateau, on the abyssal plains, and on the newly-formed volcanic buildup (epilith) in the west.

In the Albian, the Windalia Radiolarite, Gearle Siltstone, and lower Haycock Marl were deposited in various combinations across the region (Hocking et al., 1987). Figure 14C shows the general situation, with shelf mudstone near the land, marly sediments on the outer shelf, hemipelagic claystone, chalk, and calcilutite in lower neritic and upper bathyal depths, and pelagic claystone on the abyssal plains.

At Sites 762 and 763 the Gearle Siltstone consists of mudstone, marl, and limestone, is relatively thin, and is confined to the early Albian; it rests unconformably on the early Aptian or older Muderong Shale (Figs. 4 and 5). The Haycock Marl was deposited on the Gearle Siltstone, and it marks the onset of a steady increase in the proportion of pelagic carbonate and decrease in mud, which culminated in the Late Cretaceous with the deposition of chalks containing more than $80 \% \mathrm{CaCO}_{3}$ (Fig. 6).

\section{Sea Level, Tectonism, and Sedimentation}

When one considers the relationship between the sedimentary sequences at Sites 762, and 763, and global eustatic rises and falls in sea level, as documented by transgressions and regressions (Haq et al. 1987, 1988; Fig. 10), some tentative correlations can be made. However, the correlations are fraught with problems, not the least of which is that the endemic microplankton zones of Helby et al. (1987) are extremely difficult to correlate with worldwide biostratigraphic schemes. The nannofossil and microplankton ages differ considerably; for example, Sample $122-763 \mathrm{C}-54 \mathrm{X}-\mathrm{CC}$ is late Berriasian from microplankton and middle Valanginian from nannofossils. Such a disparity makes a great difference in relating sea-level fluctuations to ages.

Assuming the microplankton ages are correct, the Barrow Group appears to have been laid down during a period when global sea level was higher than it is now, within which four third-order eustatic cycles are reflected in the seismic records and well logs (Erskine and Vail, 1988; Boyd et al., this volume). However, Boyd et al. (this volume) produce seismic stratigraphic evidence that the top of the Barrow delta was always above sea level, and postulate that continuing tectonic uplift more than outweighed any eustatic sea level effects.

A major unconformity, between the early Valanginian top of the Barrow Group and the Hauterivian base of the Muderong Shale at Sites 762 and 763 , may be related to a major fall in sea level in the late Valanginian (Fig. 10). However, eustatic effects may well have continued to be subsidiary to the tectonic effects caused by the Neocomian breakup of Gondwanaland.
The post-breakup late Neocomian and Aptian transgression, which carried the Muderong Shale over the Barrow delta and all other sequences in the Carnarvon Basin, was almost certainly strongly influenced by the general rise in sea level at that time, and indeed even by the third-order eustatic cycles (Fig. 10). However, this was also a period when much of the outer Carnarvon Basin (including the Exmouth Plateau) was sinking in response to the cooling and sinking of oceanic crust around its margins, so that the sea-level rise was caused by both tectonism and eustasy.

A brief period of nondeposition or erosion in the later Aptian may have been caused by a sea-level fall (either LZB 4.1 or 4.2 in Fig. 10). This hiatus extends over nearly 5 m.y. at Site 762 but is shorter at Site 763 .

A prolonged eustatic sea-level rise in the Albian to Turonian (Fig. 10) was paralleled by steady subsidence of the Exmouth Plateau, and the result was a general deepening of the depositional environment, as the mudstones and marls of the Gearle Siltstone and the Haycock Marl were laid down. The late Turonian fall in sea level may have caused the slight change in depositional environment which gave rise to the Toolonga Calcilutite.

In the Late Cretaceous, water depths were bathyal after Toolonga deposition and the slight general fall in sea level and the various third-order eustatic rises and falls had little apparent effect on pelagic carbonate sedimentation. The Cretaceous-Cenozoic boundary is marked by a widespread regression across most of the Northwest Shelf, and this was followed by a major Paleocene regression (Bradshaw et al., 1988). On the central Exmouth Plateau there was post-Campanian reworking of late Campanian chalks at Site 763 by current or wave action, and no net deposition there until the middle Eocene.

\section{ACKNOWLEDGMENTS}

The authors wish to thank many shipboard and shorebased workers involved in the evaluation of the results of ODP Leg 122 for exchanges of ideas and drafts of papers, which allowed the accuracy of this paper to be greatly improved. In this context, special mention must be made of Ulrich von Rad, Wolfram Brenner, Robin Helby, Dick Buffler, Roy Wilkens, and Ron Boyd. The critical reviews of the draft paper by Boyd, von Rad, and Peter Barber (Phillips Australian Oil Company) led to substantial improvements to the text. We wish to thank BMR technicians Greg Sparksman, Peter Davis, and Paul Attenborough for the sedimentological studies, the BMR drawing office (and especially Rex Bates) for producing most of the figures, and Pat Burrell for typing the paper. Exon publishes with the permission of the Executive Director, Bureau of Mineral Resources, Canberra.

\section{REFERENCES}

Apthorpe, M. C., 1979. Depositional history and paleogeography of the Upper Cretaceous of the North West Shelf based on foraminifera. APEA J., 19(1):74-89.

Barber, P. M., 1982. Paleotectonic evolution and hydrocarbon genesis of the central Exmouth Plateau. APEA J., 22(1):131-144

1988. The Exmouth Plateau deep water frontier: a case history. In Purcell, P. G., and Purcell, R. R. (Eds.), The North West Shelf, Australia: Proc. Pet. Expl. Soc. Aust. Symp., 173-187.

Belford, D. J., 1958. Stratigraphy and micropalaeontology of the Upper Cretaceous of Western Australia. Geol. Rundsch., 47:629-647.

Belford, D. J., and Scheibnerova, V., 1972. Turonian foraminifera from the Carnarvon Basin, Western Australia, and their palaeogeographical significance. Micropaleontology, 17:331-344.

Boote, D.R.D., and Kirk, R. B., 1989. Depositional wedge cycles on evolving plate margin, western and northwestern Australia. AAPG Bull., 73:216-243. 
Bradshaw, M. T., Yeates, A. N., Beynon, R. M., Brakel, A. T., Langford, R. P., Totterdell, J. M., and Yeung, M., 1988. Paleogeographic evolution of the North West Region. In Purcell, P. G., and Purcell, R. R. (Eds.) The North West Shelf, Australia: Proc. Pet. Expl. Soc. Aust. Symp., 29-54.

Cockbain, A. E., 1989. The North West Shelf. APEA J., 29(1):529545.

Dickinson, W. R., 1985. Interpreting provenance relations from detrital modes of sandstones. In Zuffa, G. G. (Ed.), Provenance of Arenites: Dordrecht (D. Riedel), 333-361.

Eriyagama, S. C., Collins, L. B., and Hocking, R. M., 1988. Depositional framework and major lithostratigraphic variations of the Barrow Group. In Purcell, P. G., and Purcell, R. R. (Eds.), The North West Shelf, Australia. Proc. Pet. Explor. Soc. Aust. Symp., 189-201.

Erskine, R., and Vail, P. R., 1988. Seismic stratigraphy of the Exmouth Plateau. In Bally, A. W. (Ed.), Atlas of Seismic Stratigraphy (Vol. 2). AAPG Stud. in Geol., 27:163-173.

Exon, N. F., and Willcox, J. B., 1978. Geology and petroleum potential of the Exmouth Plateau area off Western Australia. AAPG Bull., 62:40-72.

1980. The Exmouth Plateau: stratigraphy, structure and petroleum potential. Bull. Bur. Miner. Resour. Geol. Geophys. Aust., No. 199.

Fullerton, L. G., Sager, W. W., and Handschumacher, D. W., 1989. Late Jurassic-Early Cretaceous evolution of the eastern Indian Ocean adjacent to Northwest Australia. J. Geophys. Res., 94:2937-2953.

Haq, B. U., Hardenbol, J., and Vail, P. R., 1987. Chronology of fluctuating sea levels since the Triassic. Science, 235:1156-1167. 1988. Mesozoic and Cenozoic chronostratigraphy and cycles of sea-level change. In Wilgus, C., et al., (Eds.), Sea-Level Change-An Integrated Approach. Soc. Econ. Paleontol. Mineral. Spec. Publ., 42:71-108.

Haq, B. U., von Rad, U., O'Connell, S., et al., 1990. Proc. ODP, Init. Repts., 122: College Station, TX (Ocean Drilling Program).

Heath, R. S., and Apthorpe, M. C., 1984. New formation names for the Late Cretaceous and Tertiary sequence of the southern North West Shelf. Geol. Surv. West. Aust. Rec., 1984/7.

Helby, R., Morgan, R., and Partridge, A. D., 1987. A palynological zonation of the Australian Mesozoic. In Jell, P. A. (Ed.), Studies in Australian Mesozoic Palynology. Mem. Assoc. Australas. Palaeontol., 4:1-94.

Hocking, R. M., Moors, M. T., and van der Graaff, W.J.E., 1987. The geology of the Carnarvon Basin, Western Australia. Bull.-Geol. Surv. West. Aust., 133.
Ludden, J. N., Gradstein, F. M., et al., 1990. Proc. ODP, Init. Repts., 123: College Station, TX (Ocean Drilling Program).

McClure, I. M., Smith, D. N., Williams, A. F., Clegg, J. F., and Ford, C. C., 1988. Oil and gas fields in the Barrow Sub-basin. In Purcell, P. P. and Purcell, R. R. (Eds.), The North West Shelf, Australia. Proc. Pet. Expl. Soc. Aust. Symp., 371-390.

Parry, J. C., and Smith, D. N., 1988. The Barrow and Exmouth sub-basins. In Purcell, P. G., and Purcell, R. R. (Eds.), The North West Shelf, Australia. Pet. Expl. Soc. Aust. Symp., 129-145.

Powell, D. E., 1976. The geological evolution and hydrocarbon potential of the continental margin off northwest Australia. APEA J., 16(1):13-24.

Roth, P. H., 1978. Cretaceous nannoplankton biostratigraphy and oceanography of the northwestern Atlantic Ocean. In Benson, W. E., Sheridan, R. E., et al., Init. Repts. DSDP, 44: Washington (U.S. Govt. Printing Office), 731-760.

Scholle, P. E., and Arthur, M. A., 1980. Carbon isotope fluctuations in Cretaceous pelagic limestones: potential stratigraphic and petroleum exploration tool. AAPG Bull., 64:67-87.

Veevers, J. J., Heirtzler, J. R., et al., 1974. Init. Repts. DSDP, 27: Washington (U.S. Govt. Printing Office).

Veevers, J. J., and Powell, C. McA., 1979. Sedimentary wedge progradation from transform-faulted continental rim: southern Exmouth Plateau, western Australia. AAPG Bull., 63:2088-2096.

Willcox, J. B., and Exon, N. F., 1976. The regional geology of the Exmouth Plateau. APEA J., 16(1):1-11.

Wiseman, J. F., 1979. Neocomian eustatic changes: biostratigraphic evidence from the Carnarvon Basin. APEA J., 19(1):67-73.

Woodside Offshore Petroleum, 1988. A review of the petroleum geology and hydrocarbon potential of the Barrow-Dampier subbasins and environs. In Purcell, P. G., and Purcell, R. R. (Eds.), The North West Shelf, Australia Proc. Pet. Expl. Soc. Aust. Symp., 115-128.

Wright, A. J., and Wheatley, T. J., 1979. Trapping mechanisms and the hydrocarbon potential of the Exmouth Plateau. APEA J., 19(1):19-29.

Yeates, A. N., Bradshaw, M. T., Dickens, J. M., Brakel, A. T., Exon, N. F., Langford, R. P., Mullholland, S. M., Totterdell, J. M., and Yeung, M., 1986. The Westralian superbasin: an Australian link with Tethys. In McKenzie, K. G. (Ed.), Shallow Tethys 2: Rotterdam (A. A. Balkema), 199-213.

Date of initial receipt: 31 July 1990

Date of acceptance: 2 March 1991

Ms 122B-144 


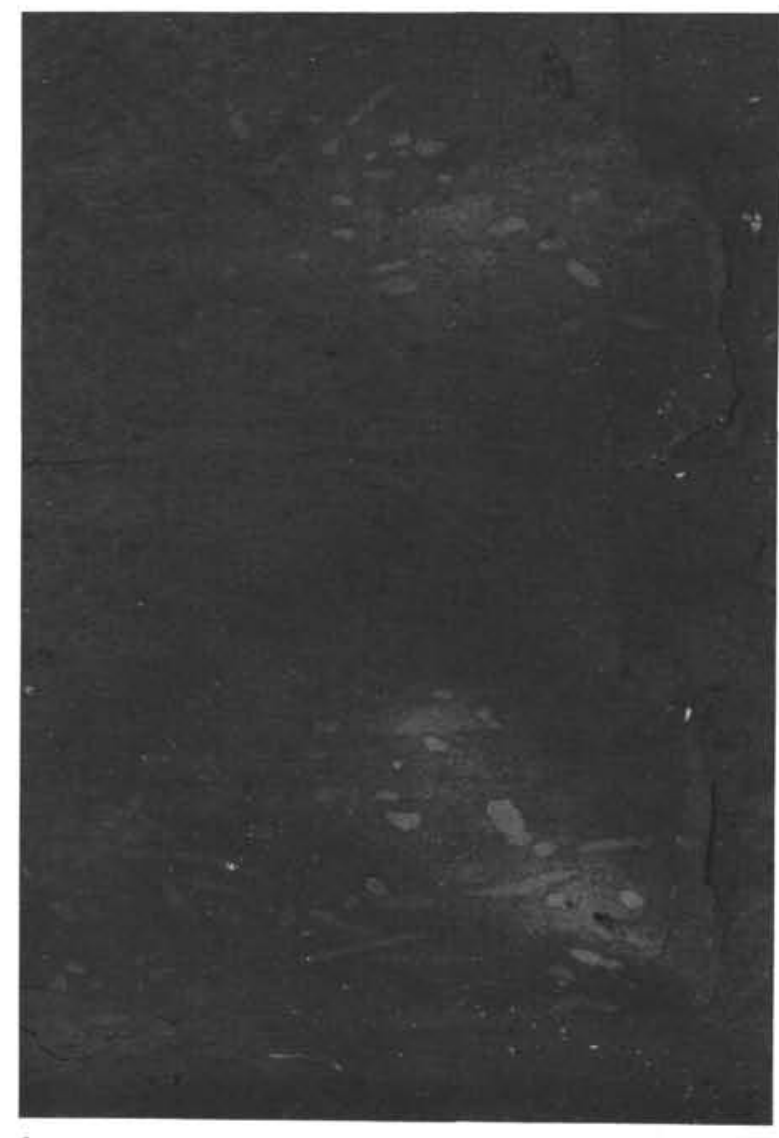

1

$1 \mathrm{~cm}$

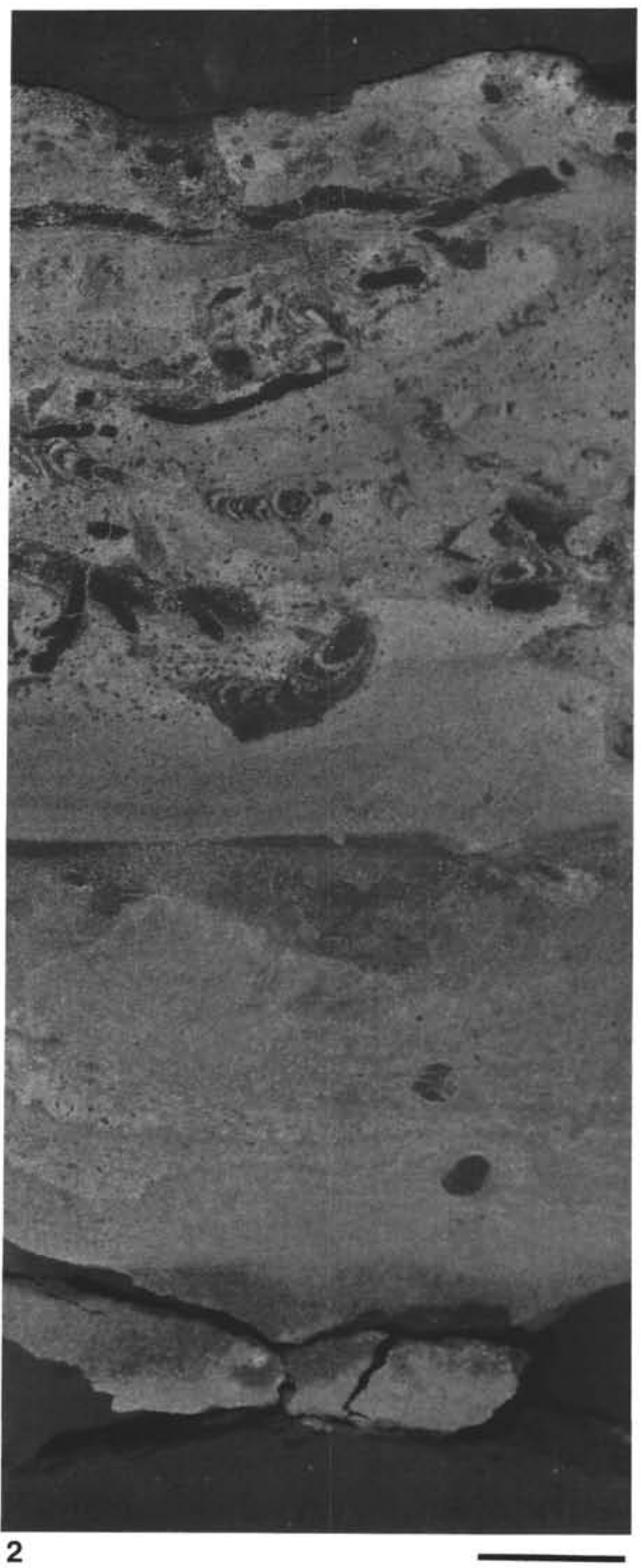

$1 \mathrm{~cm}$

Plate 1. Core photographs in Berriasian Barrow Group. 1. Section 122-763C-20R-4 at 784.7 mbsf, showing black bioturbated mudstone. Bioturbation is largely horizontal and was formed by small organisms in these sediments which contain almost $1 \%$ total organic carbon. 2. Section $122-763 \mathrm{C}-30 \mathrm{R}-3$ at $880.5 \mathrm{mbsf}$, showing 10 -cm-thick sandstone bed in black prodelta mudstones. The sandstone is fine-grained, sideritic and heavily bioturbated, with sharp upper and lower boundaries, and represents a turbidite derived from the delta front. 

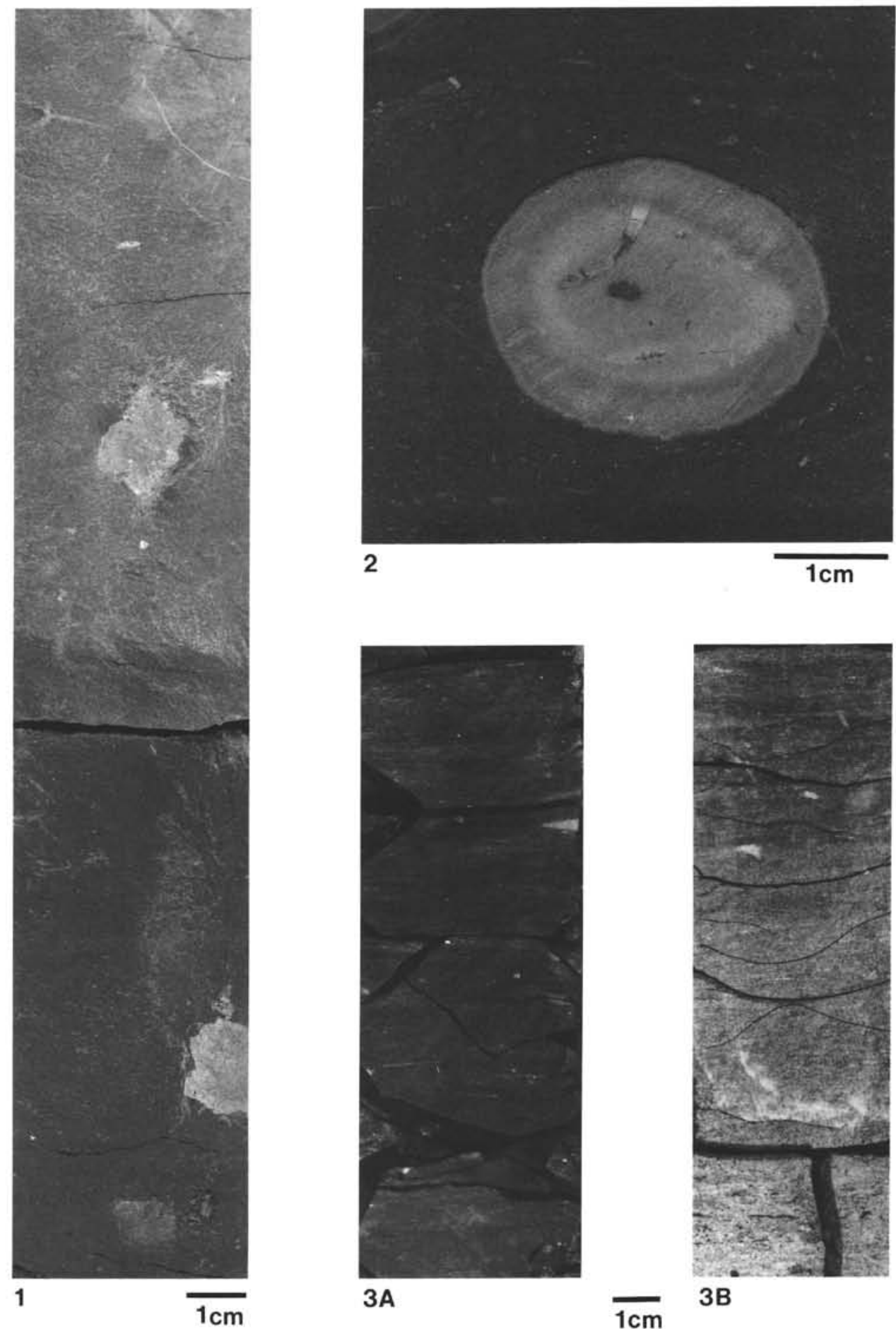

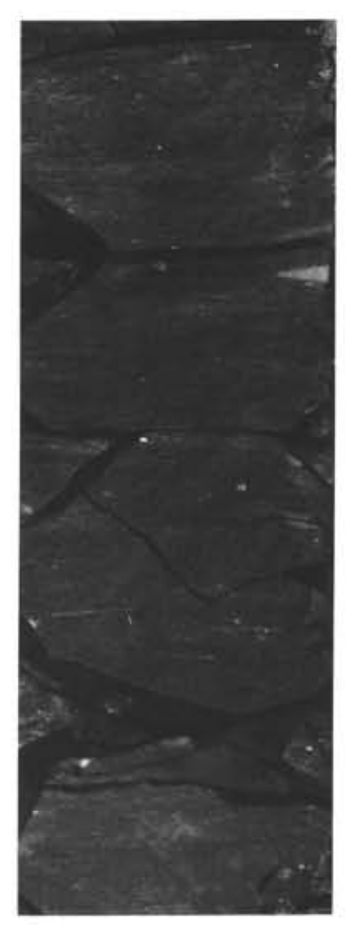

3A

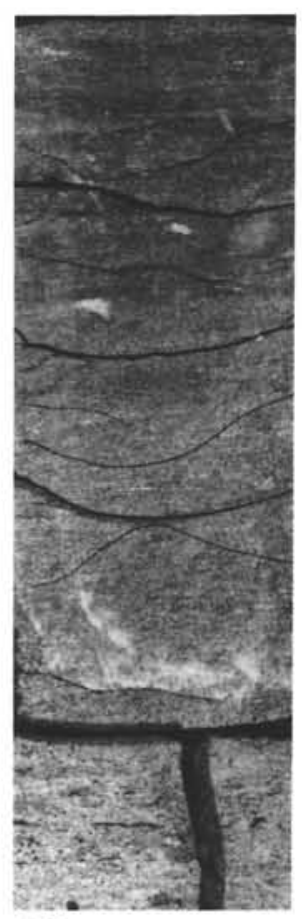

3B

Plate 2. Core photographs in Berriasian Barrow Group and early Aptian Muderong Shale. 1. Section 122-763C-2OR-1 at 781 mbsf in Barrow Group, showing black prodelta mudstone and calcite-cemented clayey quartz sandstone. Massive mudstone contains large pyrite nodules. Sandstone is fine-grained, contains pyrite nodules, and is cut by calcite veins. It is probably a diagenetically cemented turbidite bed. 2. Section 122-763C-45R-6 at 1026 mbsf in Barrow Group is black prodelta mudstone with siderite concretions. Mudstone contains shell and plant debris, quartz, and pyritized burrows. The early diagenetic concretions formed around large burrows. 3A, -B. Parts of Sections 122-762C-79X-1 and $-79 \mathrm{X}-2$ at about $840 \mathrm{mbsf}$ in Muderong Shale, showing gray mudstone (A) which grades to sandstone (B). Sandstone contains abundant shelly fossils and grades upward to mudstone. These outer shelf sediments contain pyrite, plant debris, and nannofossils. 

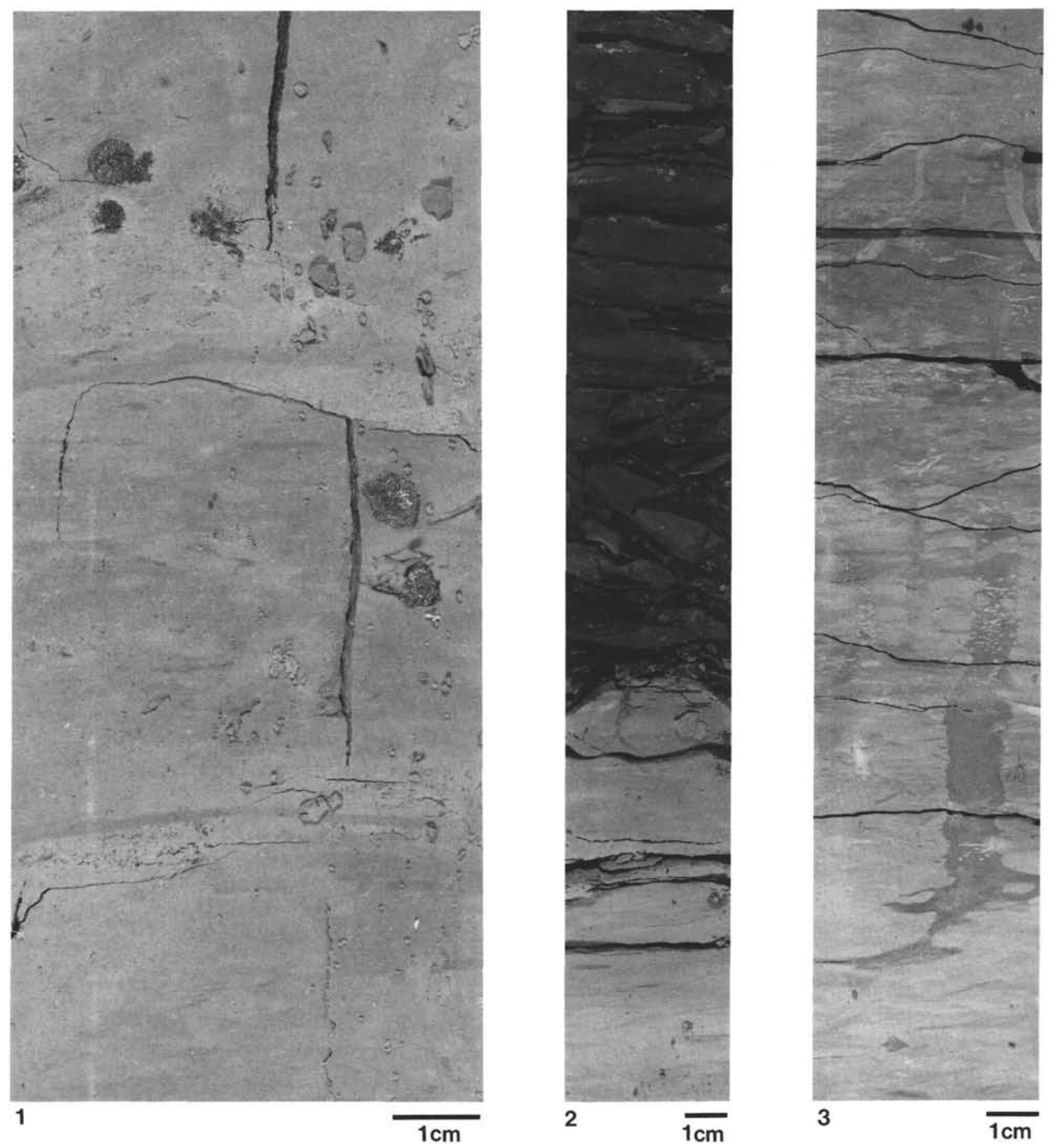

Plate 3. Core photographs in Haycock Marl. 1. Section 122-763B-31X-2 at 468 mbsf, showing middle Albian greenish gray calcareous claystone with large pyrite nodules. Thin, more sandy beds contain fine framboidal pyrite and dolomite rhombs. Subhorizontal bioturbation is evident. 2. Section 122-762C-75X-2 at 812 mbsf just below dark shales at Cenomanian-Turonian boundary (PI. 1, Fig. 3). Consists of clayey nannofossil chalk, with darker more clayey layers. Vertical and horizontal burrows are common, indicating organic-rich sediment. 3. Section 122-762C-75X-1 at $810.5 \mathrm{mbsf}$, showing dark shales at Cenomanian-Turonian boundary, underlain by nannofossil chalk. The shales represent a worldwide anoxic event and slow sedimentation. Onset of anoxic sedimentation was sudden, but its demise relatively gradual. The shales produce a regional gamma-ray log kick. 